\author{
Kamil KRASUSKI, Ewelina KOBIAŁKA, Janusz ĆWIKLAK, \\ Marek GRZEGORZEWSKI \\ Polish Air Force University (Lotnicza Akademia Wojskowa)
}

\title{
THE POSITIONING OF THE AIRCRAFT USING GPS/GLONASS DATA
}

\section{Pozycjonowanie statku powietrznego z użciem danych GPS/GLONASS}

\begin{abstract}
The article presents the results of aircraft positioning using GPS/GLONASS data in air navigation. In the work, the flight trajectory of the Cessna 172 aircraft was determined on the basis of GPS, GLONASS and GPS/GLONASS data. The coordinates of the Cessna 172 were determined using the least squares method in a stochastic processing compliant with the ICAO recommendations. In the air test, the Cessna 172 made a test flight over EPDE military airfield in Dęblin. The GPS, GLONASS and GPS/GLONASS measurement data from the Topcon HiperPro on-board aircraft installed on the Cessna 172 aircraft were used in the research experiment. The coordinates of the Cessna 172 in the geocentric XYZ and ellipsoidal BLh were compared with the precise flight reference trajectory determined from the differential technique RTK-OTF.
\end{abstract}

Keywords: GPS, GLONASS, accuracy, precision, SPP method, aircraft

Streszczenie: $W$ artykule dokonano przedstawienia rezultatów pozycjonowania statku powietrznego z uzyciem danych GPS/GLONASS w nawigacji lotniczej. W pracy dokonano wyznaczenia trajektorii lotu statku powietrznego Cessna 172 na podstawie danych GPS, GLONASS oraz GPS/GLONASS. Wspótrzędne statku powietrznego Cessna 172 zostały określone z użyciem metody najmniejszych kwadratów w procesie stochastycznym zgodnym z zaleceniami ICAO. W teście lotniczym statek powietrzny Cessna 172 dokonat próbnego oblotu lotniska wojskowego EPDE w Dęblinie. Weksperymencie badawczym wykorzystano dane pomiarowe GPS, GLONASS oraz GPS/GLONASS z pokładowego odbiornika Topcon HiperPro zainstalowanego na statku powietrznym Cessna 172. Wyznaczone wspótrzędne statku powietrznego Cessna 172 w układzie geocentrycznym XYZ oraz elipsoidalnym BLh, zostały porównane z precyzyjna trajektoria odniesienia lotu wyznaczona z techniki różnicowej $R T K-O T F$.

Słowa kluczowe: GPS, GLONASS, dokładność, precyzja, metoda SPP, statek powietrzny 


\section{Introduction}

Following the recommendations made by the Civil Aviation Authority in Poland, GPS and GLONASS satellite navigation systems are used for the exploitation of aircraft for its precise positioning during air operations [1] Therefore, the position of an aircraft can be determined using GPS, GLONASS data and a combined GPS/GLONASS solution. In the GPS satellite system, aircraft coordinates are referenced to the global reference system WGS-84. In case of the GLONASS navigation system, the designated aircraft coordinates are referenced to the global reference system PZ-90.11. What is more, in the GPS/GLONASS solution, the determined position of an aircraft is referenced to the global reference system WGS-84 or PZ-90.11[2, 3].

In the process of determining an aircraft position, GPS, GLONASS and GPS/GLONASS code observations are used at L1-C/A frequency. The use of GPS and GLONASS L1-C/A code observations is widely used in the SPP method of code positioning (Single Point Positioning) of air navigation [4]. In addition, in navigational calculations, in the absolute SPP method, a GPS and GLONASS data message is used to determine the coordinates of a satellite in orbit. The position of the GPS satellite is determined using a Kepler orbit model, whereas of the GLONASS satellite by means of the 4th-order Runge-Kutta method. In the computational process, the observation model of determining the coordinates of an aircraft additionally contains satellite clock corrections, receiver corrections, ionospheric and tropospheric corrections, relativistic correction, hardware delay, and the multipath effect. The satellite clock correction is determined using a second-degree polynomial in the GPS system, and a first-degree polynomial in the GLONASS system. The correction of the receiver clock is determined along with aircraft coordinates. The ionospheric correction in the GPS and GLONASS system is determined using the Klobuchar model. On the other hand, the tropospheric correction is determined from the deterministic model, for example the Hopfield or Saastamoinen models. The relativistic correction in the GPS system is determined using on-board message data, whereas in the GLONASS system it is contained in the satellite clock correction parameter. The group delay parameter of sending a signal in the GPS system is determined from an on-board message, and is referred to as TGD (Time Group Delay), however, in the GLONASS system, in the onboard message, there is no information on the value of group delay of sending a satellite signal. Therefore, the group delay parameter of sending a signal is involved in the satellite clock correction. The multipath correction effect is determined using a deterministic model $[5,6,7]$. 
It should be stressed that aircraft coordinates are determined using the least squares method with the weighting of code observations [1]. The weighting of code observations in the process of designating aircraft coordinates is determined in the function of the GPS or GLONASS elevation angle [8]. The final set of aircraft coordinates in the GPS, GLONASS or GPS/ GLONASS solution are expressed in the XYZ geocentric system or in the ellipsoidal BLH frame [9].

The aim of this article is to present the results of an aircraft position on the basis of the GPS, GLONASS and GPS/GLONASS solution. In the article, the authors designated the position of an aircraft taking into account GPS and GLONASS systematic, geometrical and instrumental errors. A new solution featured in the work is to show a comparison of the designated aircraft coordinates from the SPP code method in relation to a precise flight trajectory from the RTKOTF differential technique. The presented research findings indicate the order of magnitude of the results of the SPP code positioning accuracy, using the GPS, GLONASS and GPS/GLONASS navigation system in Polish aviation.

\section{Mathematical model}

The basic observation equation of the SPP method of code positioning, in air navigation, may be expressed as follows $[10,11,12]$ :

- for the GPS solution:

$$
l_{G P S}=d_{G P S}+c \cdot\left(d t r_{G P S}-d t s_{G P S}\right)+I_{O N} n_{G P S}+\operatorname{Trop}_{G P S}+\operatorname{Re} l_{G P S}+b s_{G P S}+M p_{G P S}
$$

- for the GLONASS solution:

$$
l_{G L O}=d_{G L O}+c \cdot\left(d t r_{G L O}-d t s_{G L O}\right)+\operatorname{Ion}_{G L O}+\operatorname{Trop}_{G L O}+\operatorname{Re} l_{G L O}+b s_{G L O}+M p_{G L O}
$$

- for the GPS/GLONASS solution:

$$
\left\{\begin{array}{c}
l_{G P S}=d_{G P S}+c \cdot\left(d t r_{G P S}-d t s_{G P S}\right)+I_{G o n_{G S}}+\operatorname{Trop}_{G P S}+\operatorname{Re} l_{G P S}+b s_{G P S}+M p_{G P S} \\
l_{G L O}=d_{G L O}+c \cdot\left(d t r_{G L O}-d t s_{G L O}\right)+\operatorname{Ion}_{G L O}+\operatorname{Trop}_{G L O}+\operatorname{Re} l_{G L O}+b s_{G L O}+M p_{G L O}
\end{array}\right.
$$

where: 
$l_{G P S}-\mathrm{L} 1-\mathrm{C} / \mathrm{A}$ code measurement in the GPS system,

$d_{G P S}-$ geometric distance satellite-to-receiver in the GPS system, it contains information about orbital errors, accuracy of satellite coordinates and receiver coordinates, the phase centre of the satellite/GPS receiver antenna.

$$
d_{G P S}=\sqrt{\left(X-X_{G P S}\right)^{2}+\left(Y-Y_{G P S}\right)^{2}+\left(Z-Z_{G P S}\right)^{2}},
$$

$(X, Y, Z)$ - determined geocentric coordinates of GPS, GLONASS or GPS/GLONASS receiver antenna in the XYZ geocentric system,

$\left(X_{G P S}, Y_{G P S}, Z_{G P S}\right)$ - coordinates of the GPS satellites in orbit from on-board ephemeris,

$c \quad-$ speed of light,

$d t r_{G P S}-$ correction of GPS receiver clock,

$d t s_{G P S}$ - correction of satellite clock from on-board GPS ephemeris,

$I_{\text {Ion }}$-ionospheric correction from the on-board GPS ephemeris,

$\operatorname{Trop}_{G P S}$ - tropospheric correction from a deterministic model in the GPS system,

$\operatorname{Re} l_{G P S}$ - relativistic effect from the on-board GPS ephemeris,

$b s_{G P S}$ - total value of hardware delays for the satellite and GPS receiver,

$M p_{G P S}$ - multipath effect from the deterministic model in the GPS system.

$l_{G L O} \quad-$ L1-C/A code measurement in the GLONASS system,

$d_{G L O}-$ geometric distance satellite-to-receiver in the GLONASS system; it contains information about orbital errors, accuracy of satellite coordinates and receiver coordinates, the phase centre of the satellite/GPS receiver antenna.

$$
d_{G L O}=\sqrt{\left(X-X_{G L O}\right)^{2}+\left(Y-Y_{G L O}\right)^{2}+\left(Z-Z_{G L O}\right)^{2}},
$$

$\left(X_{G L O}, Y_{G L O}, Z_{G L O}\right)$ - coordinates of the GLONASS satellites in orbit from onboard ephemeris,

c - speed of light,

$d t r_{G L O}$ - correction of GLONASS receiver clock,

$d t s_{G L O}$ - correction of a satellite clock from on-board GLONASS ephemeris, $I_{G L O}-$ ionospheric correction in the GLONASS system, 
$\operatorname{Trop}_{G L O}$ - tropospheric correction from a deterministic model in the GLONASS system,

$\operatorname{Re} l_{G L O}$ - relativistic effect in the GLONASS system, included in the parameter of satellite clock corrections,

$b s_{G L O}$ - total value of hardware delays for the satellite and GLONASS receiver, included in the parameter of satellite clock corrections,

$M p_{G L O}$ - multipath effect from the deterministic model in the GLONASS system.

Equation (1), (2), (3) is solved using the method of least squares, taking into account GPS and GLONASS measurement weights, as below [13]:

$$
\left\{\begin{array}{c}
\mathbf{Q}_{\mathbf{X}}=\mathbf{N}^{-1} \cdot \mathbf{L} \\
\mathbf{v}=\mathbf{A} \cdot \mathbf{Q}_{\mathbf{X}}-\mathbf{d l} \\
m 0_{\text {post }}=\sqrt{\frac{[\mathbf{p v v}]}{n-k}} \\
\mathbf{C}_{\mathbf{Q x}}=m 0_{\text {post }}^{2} \cdot \mathbf{N}^{-1} \\
\mathbf{m}_{\mathbf{Q x}}=\operatorname{diag}\left(\sqrt{\mathbf{C}_{\mathbf{Q x}}}\right)
\end{array}\right.
$$

where:

Qx - vector of searched parameters,

N - normal equations vector,

A - matrix of plan,

p - matrix of weights;

L $\quad-$ vector of constant terms,

dl - vector which specifies the difference in observed and approximate coordinates computed from the model,

v - corrections vector,

$m 0_{\text {post }}$ - average unit error,

$(n-k)$ - number of degrees of freedom,

$\mathbf{C}_{\mathbf{Q x}}$ - variance-covariance matrix of average errors,

$\mathbf{m}_{\mathbf{Q x}}$ - average errors of coordinates expressed in the XYZ geocentric coordinates. 


\section{Research test and results}

In the experimental test, the position of a Cessna 172 was determined during a flight over EPDE military aerodrome in Dęblin [14]. On board the aircraft, there was a Topcon HiperPro receiver, which recorded the GPS/GLONASS observations in the kinematic mode. On the basis of the recorded GPS/GLONASS code observations, the authors designated the aircraft position in accordance with equations (1), (2), (3). The computations of the position of the Cessna 172 in the GPS, GLONASS and GPS/GLONASS solution were made in the RTKLIB v.2.4.2 programme [15]. In the first stage, the aircraft coordinates were designated in the $\mathrm{XYZ}$ geocentric system; also precision was designated in the form of average aircraft coordinate errors (parameters $\mathbf{m}_{\mathbf{Q x}}$ in the stochastic model from equation (4)). The average errors of the Cessna 172 coordinates from the GPS, GLONASS and GPS/GLONASS solution are defined as below [16]:

$$
\left\{\begin{array}{l}
m x=\mathbf{m}_{\mathbf{Q x}}(1,1) \\
m y=\mathbf{m}_{\mathbf{Q x}}(2,2) \\
m z=\mathbf{m}_{\mathbf{Q x}}(3,3)
\end{array}\right.
$$

where:

$m x$ - average error of the $\mathrm{X}$ coordinate of the aircraft, $m y$ - average error of the $\mathrm{Y}$ coordinate of the aircraft, $m z$ - average error of the $\mathrm{Z}$ coordinate of the aircraft,

Figure 1 shows precision values of determining Cessna 172 coordinates in the GPS solution. The precision values are presented as average errors of XYZ coordinates, in accordance with formula (5). The average error values along the $\mathrm{X}$ axis range from $2.8 \mathrm{~m}$ to $5.8 \mathrm{~m}$. In addition, the average value of parameter $m x$ is equal to $3.5 \mathrm{~m}$ and of the median, it is $3.1 \mathrm{~m}$, respectively. The values of average errors along the $\mathrm{Y}$ axis are between $2.2 \mathrm{~m}$ and $3.1 \mathrm{~m}$. In addition, the average value of parameter $m y$ is equal to $2.5 \mathrm{~m}$, and of the median, it is $2.4 \mathrm{~m}$, respectively. The values of average errors along the $\mathrm{Z}$ axis range from $3.4 \mathrm{~m}$ to $6.3 \mathrm{~m}$. Moreover, the average value of parameter $m z$ is equal to $4.5 \mathrm{~m}$, and of the median, it is $4.4 \mathrm{~m}$, respectively. 


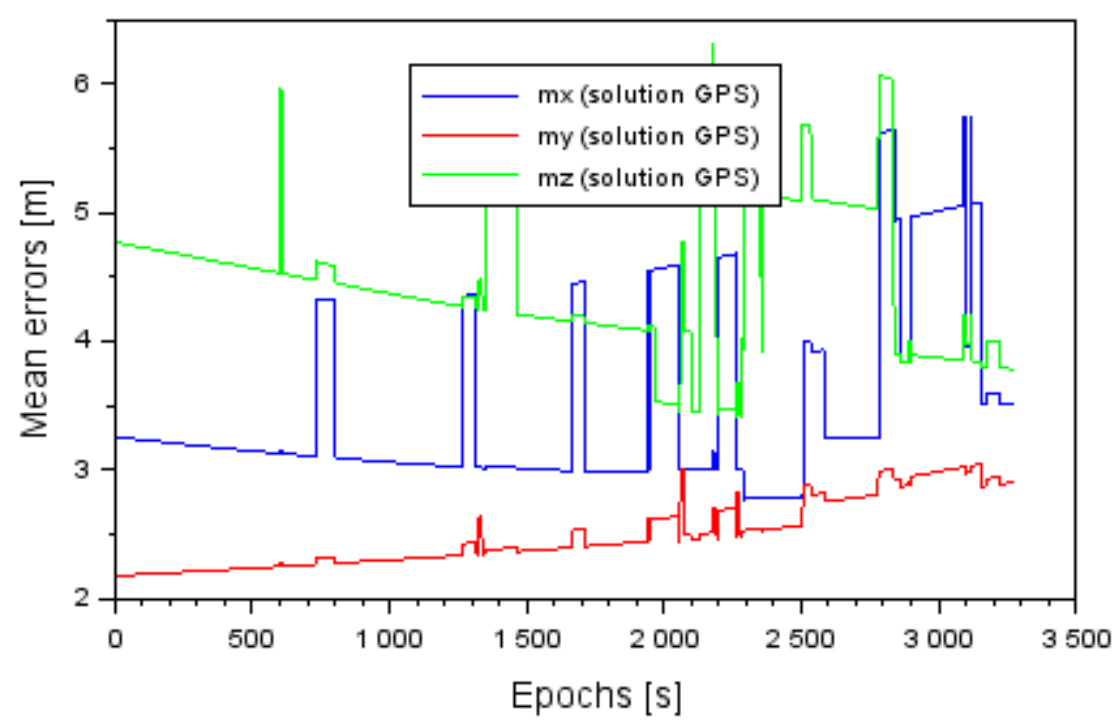

Fig. 1. Mean errors of XYZ aircraft coordinates in GPS solution

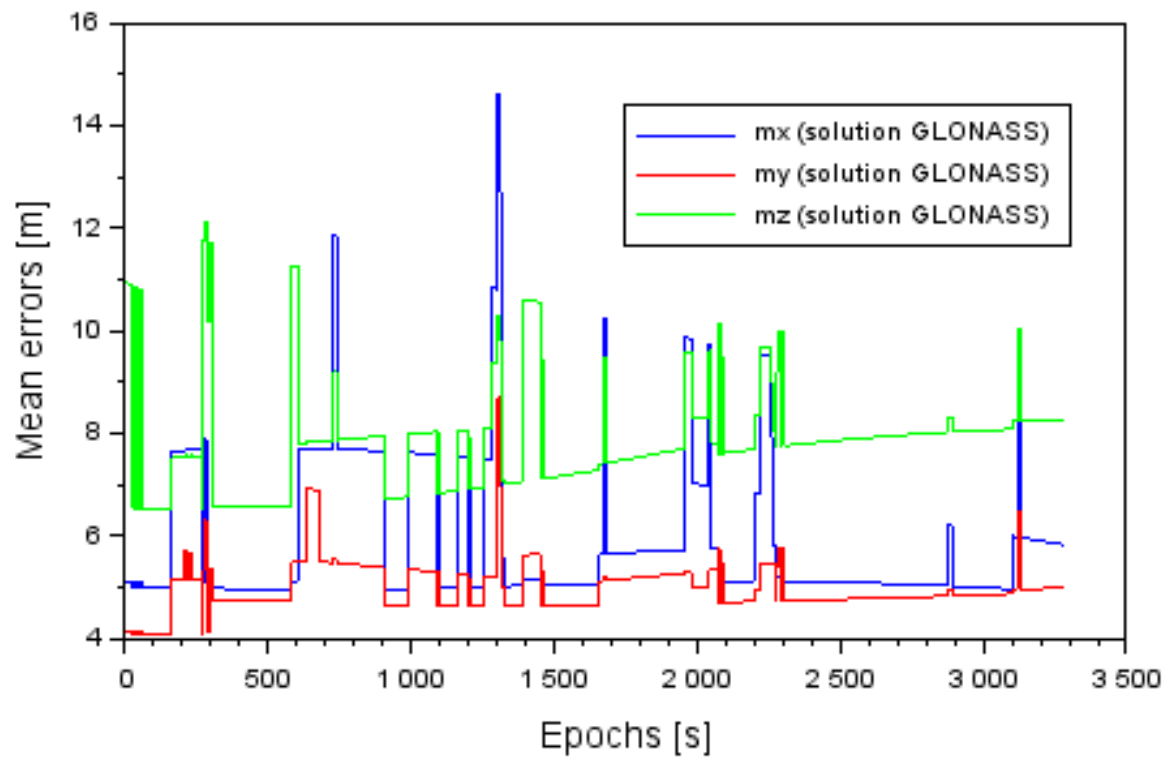

Fig. 2. Mean errors of $X Y Z$ aircraft coordinates in GLONASS solution 
Figure 2 shows precision values of determining Cessna 172 coordinates in the GLONASS solution. The precision values are presented as average errors of XYZ coordinates, in accordance with formula (5). The average error values along the $\mathrm{X}$ axis range from $5 \mathrm{~m}$ to $14.6 \mathrm{~m}$. In addition, the average value of parameter $m x$ is equal to $5.9 \mathrm{~m}$ and of the median, it is $5.1 \mathrm{~m}$, respectively. The values of average errors along the $\mathrm{Y}$ axis are between $4 \mathrm{~m}$ and $8.7 \mathrm{~m}$. In addition, the average value of parameter $m y$ is equal to $5 \mathrm{~m}$, and of the median, it is $4.8 \mathrm{~m}$, respectively. The values of average errors along the $\mathrm{Z}$ axis range from $6.5 \mathrm{~m}$ to $12.1 \mathrm{~m}$. Moreover, the average value of parameter $m z$ is equal to $7.8 \mathrm{~m}$, and of the median, it is $7.7 \mathrm{~m}$, respectively.

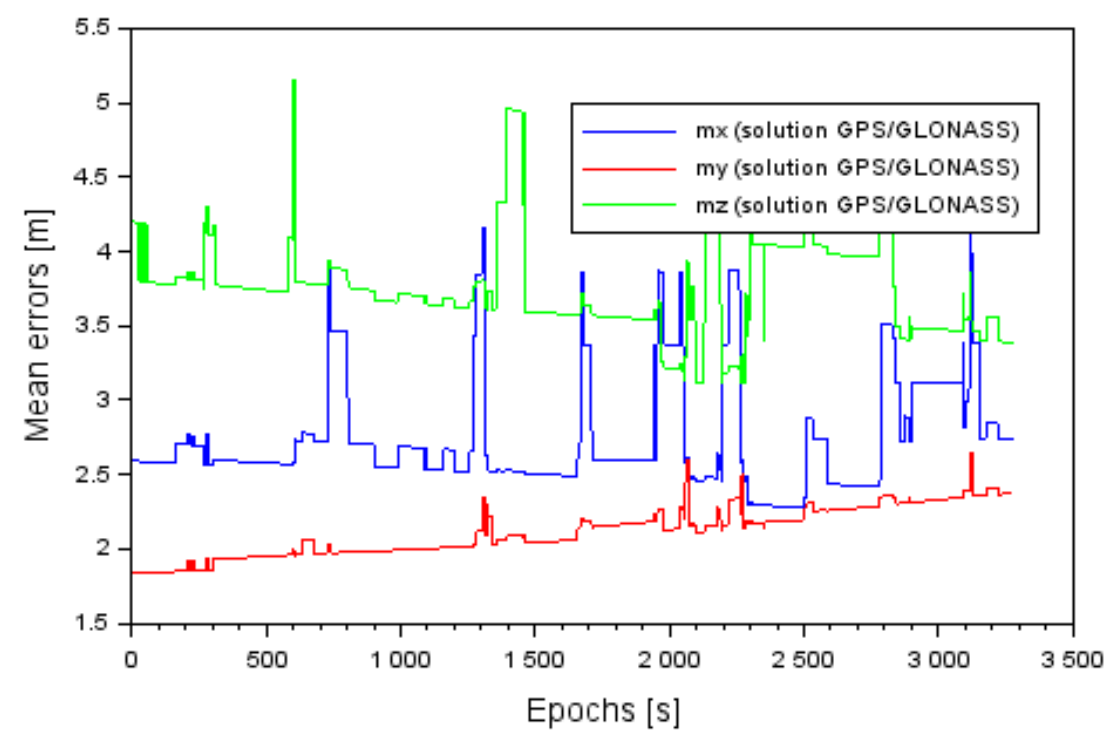

Fig. 3. Mean errors of XYZ aircraft coordinates in GPS/GLONASS solution.

Figure 3 shows precision values of determining Cessna 172 coordinates in the GPS/GLONASS solution. The precision values are presented as average errors of $\mathrm{XYZ}$ coordinates, in accordance with formula (5). The average error values along the $\mathrm{X}$ axis range from $2.3 \mathrm{~m}$ to $4.4 \mathrm{~m}$. In addition, the average value of parameter $m x$ is equal to $2.7 \mathrm{~m}$ and of the median, it is $2.6 \mathrm{~m}$, respectively. The values of average errors along the $\mathrm{Y}$ axis are between $1.8 \mathrm{~m}$ and $2.6 \mathrm{~m}$. In addition, the average value of parameter $m y$ is equal to $2.2 \mathrm{~m}$, and of the median, it is $2.1 \mathrm{~m}$, respectively. The values of average errors along the $\mathrm{Z}$ axis range from $3.1 \mathrm{~m}$ to $5.2 \mathrm{~m}$. Moreover, the average value of parameter $m z$ is equal to $3.8 \mathrm{~m}$, and of the median, it is $3.7 \mathrm{~m}$, respectively. 
In the next stage, the authors determined the accuracy of code GPS, GLONASS and GPS/GLONASS positioning in aviation. For this purpose, the aircraft coordinates from the GPS, GLONASS and GPS/GLONASS code solution were compared in relation to a precise flight trajectory, determined from the RTKOTF differential technique [17]. The precise flight trajectory from the RTK-OTF differential technique was determined using GNSS phase observations, recorded by the GNSS on-board receiver and a local reference station, installed at the aerodrome in Dęblin. In the RTK-OTF differential technique, determining the aircraft position is possible by synchronizing phase observations by an on-board receiver and a physical GNSS reference stations, at a given moment of time. Due to the RTK-OFT differential technique, the aircraft position is determined with an average error of approximately $10 \mathrm{~cm}$.

The accuracy of code GPS, GLONASS and GPS/GLONASS positioning was determined in accordance with equation (6) and (7), as below:

- in the XYZ geocentric system [18]:

$$
\left\{\begin{array}{c}
D X=X-X_{R T K-O T F} \\
D Y=Y-Y_{R T K-O T F} \\
D Z=Z-Z_{R T K-O T F}
\end{array}\right.
$$

where:

$D X$ - accuracy of positioning along the $\mathrm{X}$ axis,

$D Y$ - accuracy of positioning along the $\mathrm{Y}$ axis,

$D Z$ - accuracy of positioning along the $Z$ axis,

$(X, Y, Z)$ - designated geocentric XYZ aircraft coordinates from the GPS,

GLONASS and GPS/GLONASS solution (see equation (1), (2), (3)).

$\left(X_{R T K-O T F}, Y_{R T K-O T F}, Z_{R T K-O T F}\right)$ - precision trajectory of an aircraft flight in the

$\mathrm{XYZ}$ geocentric system in the RTK-OTF phase solution;

- in the BLH ellipsoidal frame [19]:

$$
\left\{\begin{array}{l}
d B=B-B_{R T K-O T F} \\
d L=L-L_{R T K-O T F} \\
d h=h-h_{R T K-O T F}
\end{array}\right.
$$

where:

$d B$ - accuracy of positioning along the B axis,

$d L$ - accuracy of positioning along the $\mathrm{L}$ axis,

$d h$ - accuracy of positioning along the $\mathrm{h}$ axis, 
$(B, L, h)-$ aircraft coordinates in the ellipsoidal BLH frame, resulting from the transformation of XYZ coordinates to BLH.

$\left(B_{R T K-O T F}, L_{R T K-O T F}, h_{R T K-O T F}\right)$ - precision trajectory of an aircraft flight in the BLh ellipsoidal frame in the RTK-OTF phase solution;

Figure 4 shows the results of accuracy of GPS code positioning in the XYZ geocentric system. The accuracy of GPS positioning for the Cessna 172 along the $\mathrm{X}$ axis ranged from $9 \mathrm{~m}$ to $-0.3 \mathrm{~m}$. Furthermore, the average accuracy of GPS positioning is equal to $-4.6 \mathrm{~m}$, and of the RMS error, it is $4.7 \mathrm{~m}$. The accuracy of GPS positioning for the Cessna 172 along the $Y$ axis was between $-2.6 \mathrm{~m}$ and +1.1 $\mathrm{m}$. Furthermore, the average accuracy of GPS positioning is equal to $-0.2 \mathrm{~m}$ and of the RMS error, it is $0.5 \mathrm{~m}$. The accuracy of GPS positioning for the Cessna 172 along the $\mathrm{Z}$ axis was between $5.2 \mathrm{~m}$ and $-0.2 \mathrm{~m}$. Furthermore, the average accuracy of GPS positioning equals $-3 \mathrm{~m}$ and of the RMS error, it is $3.1 \mathrm{~m}$.

Figure 5 shows the results of accuracy of GPS code positioning in the BLh ellipsoidal frame. The accuracy of GPS positioning for the Cessna 172 along the B component ranged from $-1.8 \mathrm{~m}$ to $+4.7 \mathrm{~m}$. Furthermore, the average accuracy of GPS positioning is equal to $+1.5 \mathrm{~m}$, and of the RMS error, it is $1.9 \mathrm{~m}$. The accuracy of GPS positioning for the Cessna 172 along the $\mathrm{L}$ component was between $+0.3 \mathrm{~m}$ and +2.8 $\mathrm{m}$. Furthermore, the average accuracy of GPS positioning is equal to $+1.6 \mathrm{~m}$, and of the RMS error, it is also $1.6 \mathrm{~m}$. The accuracy of GPS positioning for the Cessna 172 along the $\mathrm{h}$ axis was between $-9.1 \mathrm{~m}$ and $-1.9 \mathrm{~m}$. Furthermore, the average accuracy of GPS positioning equals $-5.1 \mathrm{~m}$, and of the RMS error, it is $5.1 \mathrm{~m}$.

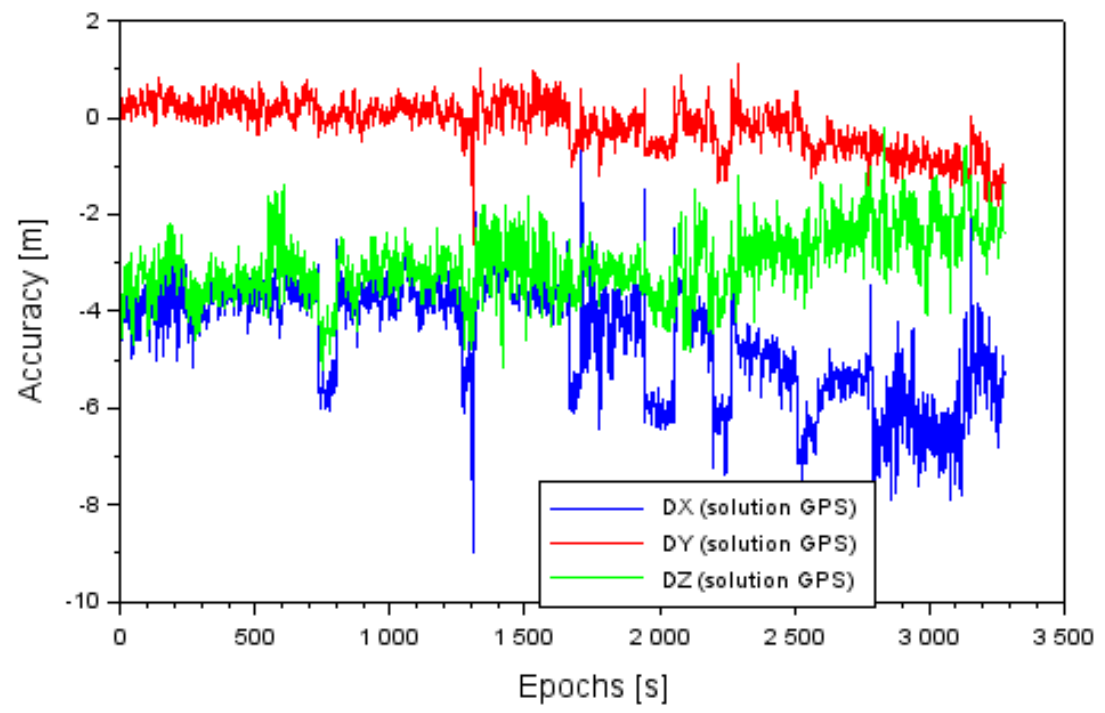

Fig. 4. Accuracy of GPS code positioning in XYZ geocentric coordinates 


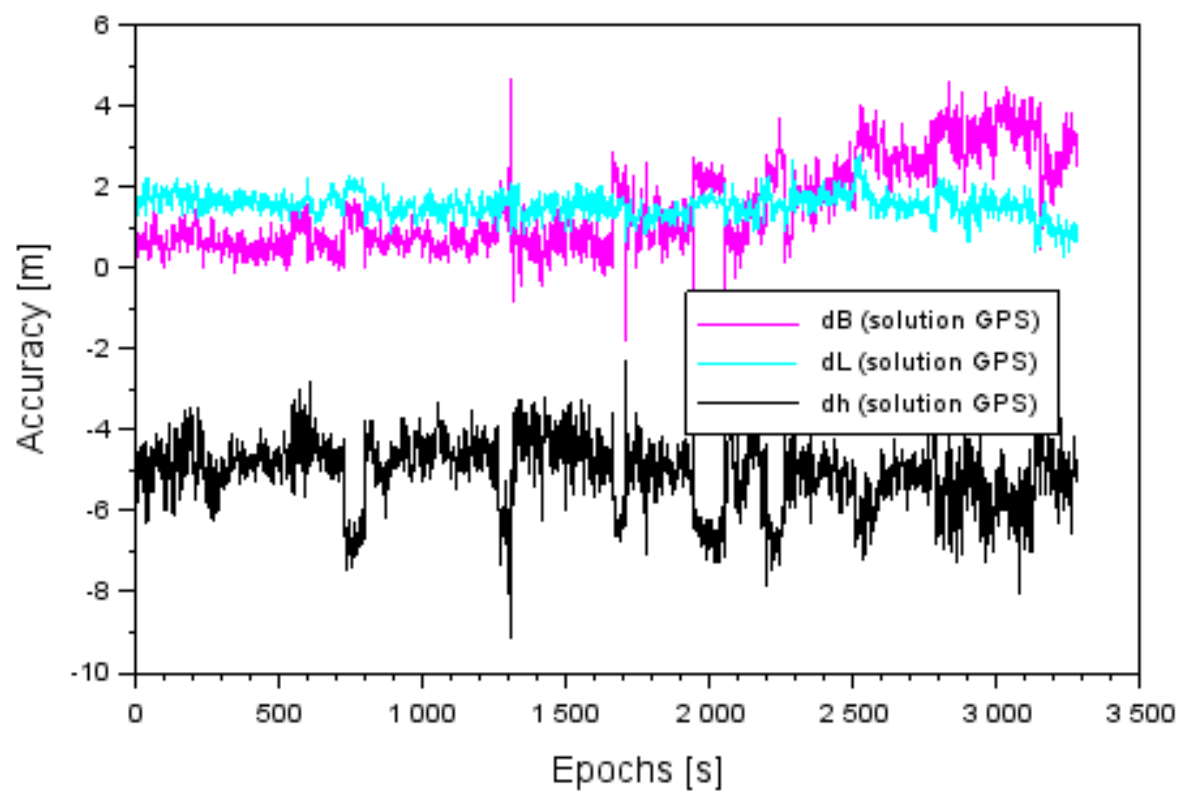

Fig. 5. Accuracy of GPS code positioning in BLh ellipsoidal coordinates

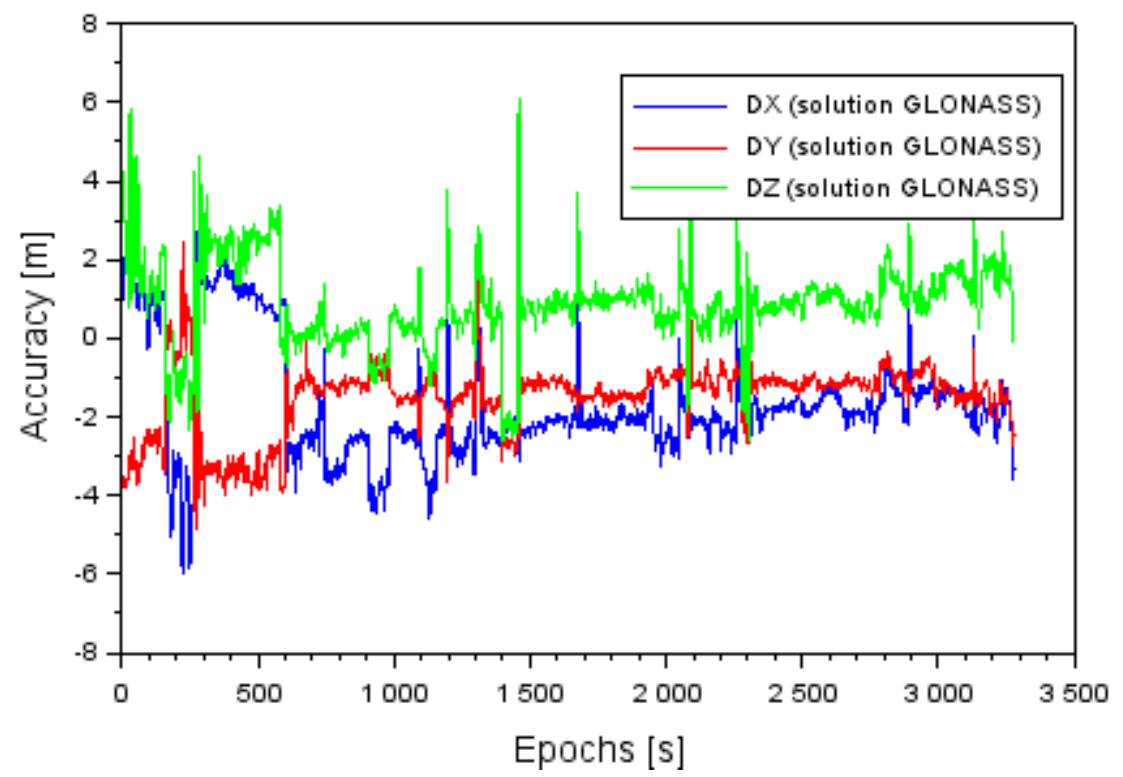

Fig. 6. Accuracy of GPS code positioning in GLONASS geocentric coordinates 


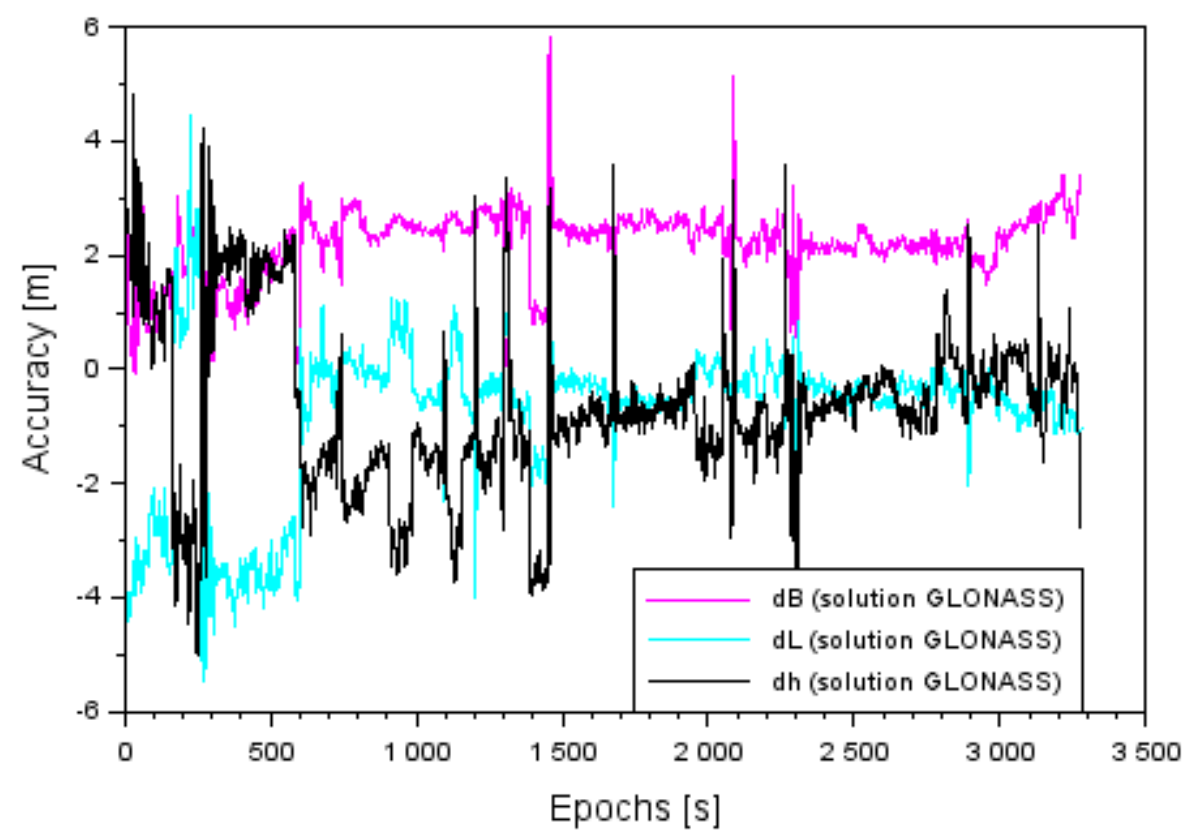

Fig. 7. Accuracy of GLONASS code positioning in BLh ellipsoidal coordinates

Figure 6 shows the results of accuracy of GLONASS code positioning in the $\mathrm{XYZ}$ geocentric system. The accuracy of GLONASS positioning for the Cessna 172 along the $X$ axis ranged from $-6 \mathrm{~m}$ to $+3.4 \mathrm{~m}$. Furthermore, the average accuracy of GLONASS positioning is equal to $-2 \mathrm{~m}$, and of the RMS error, it is 2.2 $\mathrm{m}$. The accuracy of GLONASS positioning for the Cessna 172 along the $\mathrm{Y}$ axis was between $-4.9 \mathrm{~m}$ and $+2.5 \mathrm{~m}$. Furthermore, the average accuracy of GLONASS positioning is equal to $-1.3 \mathrm{~m}$, and of the RMS error, it is $1.8 \mathrm{~m}$. The accuracy of GLONASS positioning for the Cessna 172 along the $\mathrm{Z}$ axis was between $-2.6 \mathrm{~m}$ and $+6.1 \mathrm{~m}$. Furthermore, the average accuracy of GLONASS positioning equals $+0.8 \mathrm{~m}$, and of the RMS error, it is $3.1 \mathrm{~m}$.

Figure 7 shows the results of accuracy of GLONASS code positioning in the BLh ellipsoidal frame. The accuracy of GLONASS positioning for the Cessna 172 along the $\mathrm{B}$ component ranged from $-0.3 \mathrm{~m}$ to $+5.8 \mathrm{~m}$. Furthermore, the average accuracy of GLONASS positioning is equal to $+2.3 \mathrm{~m}$, and of the RMS error, it is $2.2 \mathrm{~m}$. The accuracy of GLONASS positioning for the Cessna 172 along the $\mathrm{L}$ component was between $-5.5 \mathrm{~m}$ and $+4.8 \mathrm{~m}$. Furthermore, the average accuracy of GLONASS positioning is equal to $-0.5 \mathrm{~m}$, and of the RMS error, it is also $1.5 \mathrm{~m}$. The accuracy of GLONASS positioning for the Cessna 172 along the $h$ component 
was between $-5 \mathrm{~m}$ and $+4.8 \mathrm{~m}$. Furthermore, the average accuracy of GLONASS positioning equals $-0.8 \mathrm{~m}$, and of the RMS error, it is $1.6 \mathrm{~m}$.

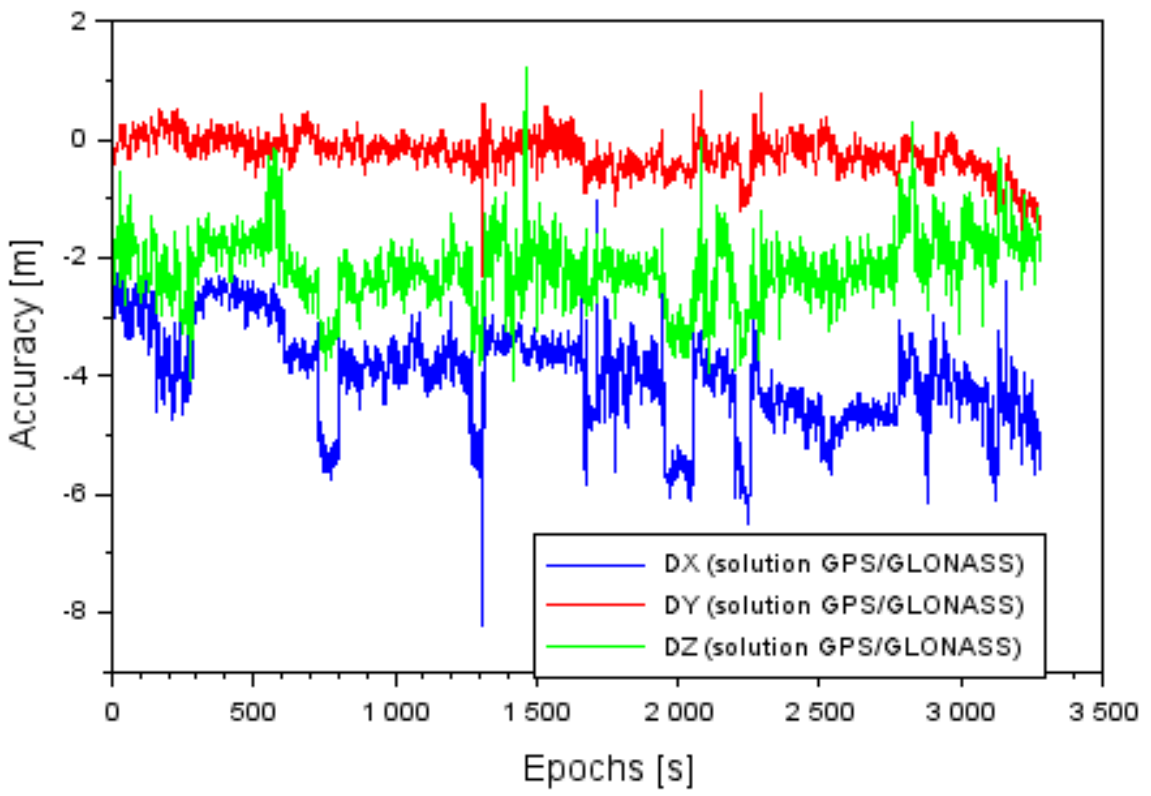

Fig. 8. Accuracy of GPS/GLONASS code positioning in XYZ geocentric coordinates

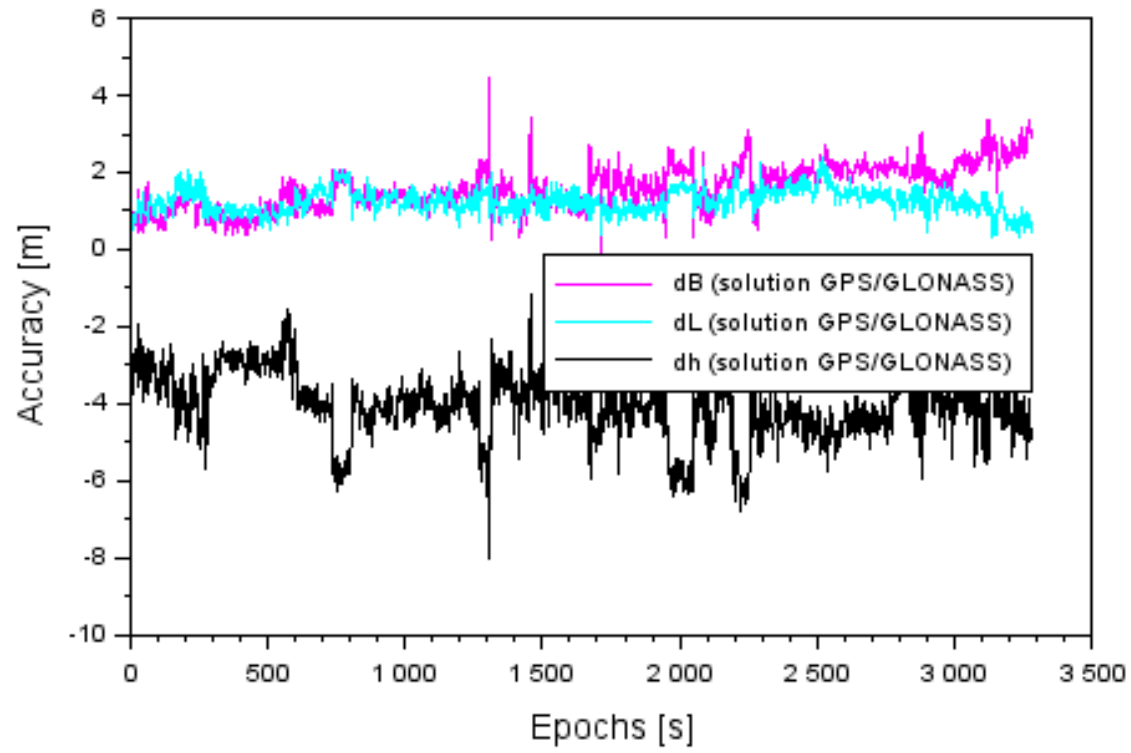

Fig. 9. Accuracy of GPS/GLONASS code positioning in BLh ellipsoidal coordinates 
Figure 8 shows the results of accuracy of GPS/GLONASS code positioning in the XYZ geocentric system. The accuracy of GPS/GLONASS positioning for the Cessna 172 along the $X$ axis ranged from $-8.2 \mathrm{~m}$ to $-1 \mathrm{~m}$. Furthermore, the average accuracy of GPS/GLONASS positioning is equal to $-3.9 \mathrm{~m}$, and of the RMS error, it is $4.1 \mathrm{~m}$. The accuracy of GPS/GLONASS positioning for the Cessna 172 along the $\mathrm{Y}$ axis was between $-2.3 \mathrm{~m}$ and $+0.8 \mathrm{~m}$. Furthermore, the average accuracy of GPS/GLONASS positioning is equal to $-0.2 \mathrm{~m}$ and of the RMS error, it is $0.4 \mathrm{~m}$. The accuracy of GPS/GLONASS positioning for the Cessna 172 along the $\mathrm{Z}$ axis was between $-4.1 \mathrm{~m}$ and $+1.2 \mathrm{~m}$. Furthermore, the average accuracy of GPS positioning equals $-2.2 \mathrm{~m}$, and of the RMS error, it is $2.3 \mathrm{~m}$.

Figure 9 shows the results of accuracy of GPS/GLONASS code positioning in the BLh ellipsoidal frame. The accuracy of GPS/GLONASS positioning for the Cessna 172 along the B component ranged from $-0.2 \mathrm{~m}$ to $+4.9 \mathrm{~m}$. Furthermore, the average accuracy of GPS/GLONASS positioning is equal to $+1.6 \mathrm{~m}$, and of the RMS error, it is $1.7 \mathrm{~m}$. The accuracy of GPS/GLONASS positioning for the Cessna 172 along the $\mathrm{L}$ component was between $+0.3 \mathrm{~m}$ and $+2.4 \mathrm{~m}$. Furthermore, the average accuracy of GPS/GLONASS positioning is equal to $+1.3 \mathrm{~m}$, and of the RMS error, it is also $1.3 \mathrm{~m}$. The accuracy of GPS/GLONASS positioning for the Cessna 172 along the $\mathrm{h}$ component was between $-8 \mathrm{~m}$ and $-1.1 \mathrm{~m}$. Furthermore, the average accuracy of GPS/GLONASS positioning equals $-4.1 \mathrm{~m}$, and of the RMS error, it is $4.2 \mathrm{~m}$.

\section{Conclusions}

The paper presents the findings of code positioning accuracy in the GPS, GLONASS and GPS/GLONASS solution, in aviation. In the research test, onboard GPS/GLONASS data from a Topcon HiperPro were used. The receiver was mounted in a Cessna 172. Furthermore, in order to determine the precise trajectory of the reference flight of the Cessna 172, the RTK-OTF differential technique was used. Therefore, in the calculations in the RTK-OTF differential technique, the authors used on-board GNSS data, from the Topcon HiperPro receiver, as well as phase observations from the GNSS reference station, installed on the grounds of the military aerodrome in Dęblin. On the basis on the conducted investigations, it was found that:

- the highest positioning accuracy along the $\mathrm{X}$ axis is for the GLONASS code solution, and the lowest for the GPS code solution,

- the highest positioning accuracy along the Y axis is for the GPS code solution, and the lowest for the GLONASS code solution, 
- the highest positioning accuracy along the $\mathrm{Z}$ axis is for the GLONASS code solution, and the lowest for the GPS code solution,

- the lowest RMS error value along the X axis is for the GLONASS code solution, and the highest for the GPS code solution,

- the lowest RMS error value along the Y axis is for the GPS/GLONASS code solution, and the highest for the GLONASS code solution,

- the lowest RMS error value along the $\mathrm{Z}$ axis is for the GLONASS code solution, and the highest for the GPS code solution,

- the highest positioning accuracy for the B component is for the GPS code solution, and the lowest for the GLONASS code solution,

- the highest positioning accuracy for the L component is for the GLONASS code solution, and the lowest for the GPS code solution,

- the highest positioning accuracy for the $\mathrm{h}$ component is for the GLONASS code solution, and the lowest for the GPS code solution,

- the lowest RMS error value along the B axis is for the GPS/GLONASS code solution, and the highest for the GLONASS code solution,

- the lowest RMS error value along the L axis is for the GPS/GLONASS code solution, and the highest for the GPS code solution,

- the lowest RMS error value along the $h$ axis is for the GLONASS code solution, and the highest for the GPS code solution.

\section{Acknowledgment}

This paper has been supported by the Polish Air Force University, Faculty of Aeronautics, Department of Air Navigation.

\section{References}

1. International Civil Aviation Organization: ICAO standards and recommended practices (SARPS). Annex 10 volume I (Radio navigation aids), 2006.

2. Misra P.N., Abbot R.I., Gaposcbkin E.M.: Integrated Use of GPS and GLONASS: Transformation Between WGS 84 and PZ-90. Proceedings of the 9th International Technical Meeting of the Satellite Division of The Institute of Navigation (ION GPS 1996), Kansas City, MO, September 1996.

3. Januszewski J.: Perspektywy rozwoju nawigacyjnych i wspomagających systemów satelitarnych w bliskiej i dalszej przyszłości. Przegląd Telekomunikacyjny + Wiadomości Telekomunikacyjne, No. 5, 2014.

4. Jafernik H., Ćwiklak J., Krasuski K.: Wykorzystanie programu gLAB w precyzyjnym pozycjonowaniu statku powietrznego w transporcie lotniczym - testy lotnicze w Dęblinie i Mielcu. Przegląd Komunikacyjny, year 73, no 1, 2018. 
5. Przestrzelski P.: Sieciowe pozycjonowanie różnicowe z wykorzystaniem obserwacji GPS i GLONASS. PhD dissertation, Olsztyn 2016.

6. Krasuski K, Ćwiklak J.: Application of the GLONASS code observations for the designation of coordinates of an aircraft in flight test mode: a case study. Scientific Journal of Silesian University of Technology. Series Transport, Vol. 97, 2017, DOI: https://doi.org/10.20858/sjsutst.2017.97.7.

7. IS-GPS-200D-001: Interface Specification IS-GPS-200 Revision D. NAVSTAR Global Positioning System, 2006.

8. Santerre R., Pan L., Cai C., Zhu J.: Single Point Positioning Using GPS, GLONASS and BeiDou Satellites. Positioning, 2014, vol. 5, DOI: 10.4236/pos.2014.54013.

9. Ćwiklak J., Krasuski K., Jafernik H.: Designation the velocity of Cessna 172 aircraft based on GPS data in flight test. 23rdInternational Conference ENGINEERING MECHANICS 2017, Svratka, Czech Republic, 15-18 May 2017.

10. Bakuła M.: Pozycjonowanie autonomiczne $\mathrm{z}$ wykorzystaniem obserwacji GPS. Zeszyty Naukowe WSOSP, No. 1, 2014.

11. Roßbrach U.: Positioning and Navigation using Russian Satellite System GLONASS. $\mathrm{Ph}$. D. Thesis, Monachium, 2000.

12. Krasuski K.: Wykorzystanie obserwacji GPS/GLONASS do wyznaczenia pozycji statku powietrznego. Zeszyty Naukowe WSOSP, No. 4, 2015.

13. Osada E.: Geodezja. Oficyna Wydawnicza Politechniki Wrocławskiej, Wrocław, 2001.

14. Krasuski K., Ćwiklak J., Grzesik N.: Accuracy assessment of aircraft positioning by using the DGLONASS method in GBAS system. Journal of KONBIN, Vol. 45, 2018, DOI: $10.1515 /$ jok-2018-0006.

15. Takasu T.: RTKLIB ver. 2.4.2 Manual, RTKLIB: An Open Source Program Package for GNSS Positioning, 2013, Paper available at website: http://www.rtklib.com/prog/manual_2.4.2.pdf, current on 2019.

16. Siejka Z.: Wykorzystanie pomiarów gnss do wyznaczania współrzędnych podstawowej osnowy realizacyjnej na terenach oddziaływań górniczych. Archiwum Fotogrametrii, Kartografii i Teledetekcji, Vol. 19, 2009.

17. Grzegorzewski M.: Navigating an aircraft by means of a position potential in three dimensional space. Annual of Navigation, No. 9, 2005.

18. Bakuła, M.: Static code DGPS positioning based on three reference stations. Geodesy and Cartography, Vol. 54, No 2, 2005.

19. Świątek A., Jaworski L., Tomasik Ł.: EGNOS Monitoring Prepared in Space Research Centre P.A.S. for SPMS Project. Artificial Satellites, Vol. 52, No. 4, 2017, DOI: 10.1515/arsa-2017-0010. 


\section{POZYCJONOWANIE STATKU POWIETRZNEGO Z UŻYCIEM DANYCH GPS/GLONASS}

\section{Wprowadzenie}

Zgodnie z zaleceniami Urzędu Lotnictwa Cywilnego w Polsce systemy nawigacji satelitarnej GPS oraz GLONASS są stosowane w eksploatacji statku powietrznego (SP) do precyzyjnego pozycjonowania w czasie wykonywania operacji lotniczej [1]. W związku z tym pozycja SP może być wyznaczana z użyciem danych GPS, GLONASS oraz wspólnego rozwiązania GPS/GLONASS. W systemie satelitarnym GPS wyznaczane współrzędne SP są odniesione do globalnego układu odniesienia WGS-84. W przypadku systemu nawigacyjnego GLONASS wyznaczane współrzędne są odniesione do globalnego układu odniesienia PZ-90.11. Z kolei w rozwiązaniu GPS/GLONASS wyznaczana pozycja SP jest odniesiona do globalnego układu odniesienia WGS-84 lub PZ-90.11 [2, 3].

$\mathrm{W}$ procesie wyznaczania pozycji statku powietrznego są wykorzystywane obserwacje kodowe GPS, GLONASS oraz GPS/GLONASS na częstotliwości L1-C/A. Zastosowanie tych obserwacji jest powszechnie stosowane w metodzie pozycjonowania kodowego SPP (Single Point Positioning) w nawigacji lotniczej [4]. Ponadto $\mathrm{w}$ obliczeniach nawigacyjnych $\mathrm{w}$ metodzie absolutnej SPP jest stosowana depesza pokładowa GPS i GLONASS do wyznaczenia współrzędnych satelity na orbicie. Pozycja satelity GPS jest określona z użyciem modelu orbity Keplerowskiej, z kolei satelity GLONASS z użyciem metody Runge-Kutta 4. rzędu. W procesie obliczeniowym model obserwacyjny wyznaczenia współrzędnych statku powietrznego zawiera dodatkowo parametry poprawki zegara satelity i odbiornika, poprawki jonosferycznej i troposferycznej, poprawki relatywistycznej i opóźnienia sprzętowego, oraz efektu wielotorowości. Poprawka zegara satelity jest określana $\mathrm{z}$ użyciem wielomianu 2. stopnia $\mathrm{w}$ systemie GPS, natomiast w systemie GLONASS z użyciem wielomianu 1. stopnia. Poprawka chodu zegara odbiornika jest wyznaczana razem ze współrzędnymi SP. Poprawka jonosferyczna w systemie GPS i GLONASS jest określona z użyciem modelu Klobuchara. Z kolei poprawka troposferyczna jest określona z modelu deterministycznego, np. model Hopfield lub Saastamoinena. Poprawka relatywistyczna w systemie GPS jest określona z użyciem danych z depeszy pokładowej, zaś w systemie GLONASS jest 
zawarta $\mathrm{w}$ parametrze poprawki chodu zegara satelity. Parametr opóźnienia grupowego wysłania sygnału w systemie GPS jest określony z depeszy pokładowej i nazywany TGD. Natomiast w systemie GLONASS w depeszy pokładowej nie ma informacji na temat wartości opóźnienia grupowego wysłania sygnału satelitarnego. W związku z tym parametr opóźnienia grupowego wysłania sygnału jest uwikłany w poprawce chodu zegara satelity. Poprawka efektu wielotorowości jest określona z użyciem modelu deterministycznego [5, 6, 7].

Należy podkreślić, że współrzędne statku powietrznego są wyznaczane z wykorzystaniem metody najmniejszych kwadratów z użyciem wag obserwacji kodowych [1]. Wagowanie obserwacji kodowych w procesie wyznaczenia współrzędnych statku powietrznego jest określona w funkcji kąta elewacji satelity GPS lub GLONASS [8]. Finalne wyznaczone współrzędne SP z rozwiązania GPS, GLONASS lub GPS/GLONASS są wyrażone w układzie geocentrycznym XYZ lub elipsoidalnym BLh [9].

Celem artykułu jest przedstawienie wyników pozycji statku powietrznego na podstawie rozwiązania GPS, GLONASS oraz GPS/GLONASS. W pracy wyznaczono pozycję SP z uwzględnianiem błędów systematycznych, geometrycznych i instrumentalnych GPS i GLONASS. Nowym rozwiązaniem w pracy jest pokazanie porównania wyznaczonych współrzędnych statku powietrznego z metody kodowej SPP względem precyzyjnej trajektorii lotu z techniki różnicowej RTK-OTF. Przedstawione w pracy wyniki badań pokazują rząd wielkości rezultatów dokładności pozycjonowania kodowego SPP z użyciem systemu nawigacyjnego GPS, GLONASS i GPS/GLONASS w polskim lotnictwie.

\section{Model matematyczny}

Podstawowe równanie obserwacyjne metody pozycjonowania kodowego SPP w nawigacji lotniczej można zapisać, jak poniżej [10, 11, 12]:

- dla rozwiązania GPS:

$$
l_{G P S}=d_{G P S}+c \cdot\left(d t r_{G P S}-d t s_{G P S}\right)+I n_{G P S}+\operatorname{Trop}_{G P S}+\operatorname{Re} l_{G P S}+b s_{G P S}+M p_{G P S}
$$

- dla rozwiązania GLONASS:

$$
l_{G L O}=d_{G L O}+c \cdot\left(d t r_{G L O}-d t s_{G L O}\right)+\operatorname{Ion}_{G L O}+\operatorname{Trop}_{G L O}+\operatorname{Re} l_{G L O}+b s_{G L O}+M p_{G L O}
$$


- dla rozwiązania GPS/GLONASS:

$$
\left\{\begin{array}{c}
l_{G P S}=d_{G P S}+c \cdot\left(d t r_{G P S}-d t s_{G P S}\right)+I_{G o n_{G S}}+\operatorname{Trop}_{G P S}+\operatorname{Re} l_{G P S}+b s_{G P S}+M p_{G P S} \\
l_{G L O}=d_{G L O}+c \cdot\left(d t r_{G L O}-d t s_{G L O}\right)+\operatorname{Ion}_{G L O}+\operatorname{Trop}_{G L O}+\operatorname{Re} l_{G L O}+b s_{G L O}+M p_{G L O}
\end{array}\right.
$$

gdzie:

$l_{G P S}-$ pomiar kodowy L1-C/A w systemie GPS,

$d_{G P S}$ - odległość geometryczna satelita-odbiornik w systemie GPS, zawiera informacje o: błędach orbity, dokładności współrzędnych satelity i odbiornika, centrum fazowym anteny satelity i odbiornika,

$$
d_{G P S}=\sqrt{\left(X-X_{G P S}\right)^{2}+\left(Y-Y_{G P S}\right)^{2}+\left(Z-Z_{G P S}\right)^{2}},
$$

$(X, Y, Z)$ - wyznaczane współrzędne geocentryczne anteny odbiornika GPS lub GLONASS lub GPS/GLONASS w układzie geocentrycznym XYZ, $\left(X_{G P S}, Y_{G P S}, Z_{G P S}\right)$ - współrzędne satelitów GPS na orbicie $\mathrm{z}$ efemerydy pokładowej,

c - prędkość światła,

$d t r_{G P S}$ - poprawka chodu zegara odbiornika GPS,

$d t s_{G P S}$ - poprawka chodu zegara satelity z efemerydy pokładowej GPS,

$I{ }^{\prime} n_{G P S}$ - poprawka jonosferyczna z efemerydy pokładowej GPS,

$\operatorname{Trop}_{G P S}$ - poprawka troposferyczna $\mathrm{z}$ modelu deterministycznego w systemie GPS,

$\operatorname{Re} l_{G P S}$ - efekt relatywistyczny z efemerydy pokładowej GPS,

$b s_{G P S} \quad$ - sumaryczna wartość opóźnień sprzętowych dla satelity oraz odbiornika GPS,

$M p_{G P S}$ - efekt wielotorowości z modelu deterministycznego w systemie GPS.

$l_{G L O} \quad$ - pomiar kodowy L1-C/A w systemie GLONASS,

$d_{G L O}$ - odległość geometryczna satelita-odbiornik w systemie GLONASS, zawiera informacje o: błędach orbity, dokładności współrzędnych satelity i odbiornika, centrum fazowym anteny satelity i odbiornika,

$$
d_{G L O}=\sqrt{\left(X-X_{G L O}\right)^{2}+\left(Y-Y_{G L O}\right)^{2}+\left(Z-Z_{G L O}\right)^{2}},
$$


$\left(X_{G L O}, Y_{G L O}, Z_{G L O}\right)$ - współrzędne satelitów GLONASS na orbicie z efemerydy pokładowej,

c - prędkość światła,

$d t r_{G L O}$ - poprawka chodu zegara odbiornika GLONASS,

$d t s_{G L O}$ - poprawka chodu zegara satelity z efemerydy pokładowej GLONASS, $I_{\text {IoLO }}$ - poprawka jonosferyczna w systemie GLONASS,

$\operatorname{Trop}_{G L O}$ - poprawka troposferyczna z modelu deterministycznego w systemie GLONASS,

$\operatorname{Re} l_{G L O}$ - efekt relatywistyczny w systemie GLONASS, uwikłany w parametr poprawki chodu zegara satelity,

$b s_{G L O}$ - sumaryczna wartość opóźnień sprzętowych dla satelity oraz odbiornika GLONASS, uwikłana w parametr poprawki chodu zegara satelity, $M p_{G L O}$ - efekt wielotorowości $\mathrm{z}$ modelu deterministycznego w systemie GLONASS.

Równania (1), (2), (3) są rozwiązywane metodą najmniejszych kwadratów z uwzględnieniem wag pomiarów GPS i GLONASS, jak poniżej [13]:

$$
\left\{\begin{array}{c}
\mathbf{Q}_{\mathbf{X}}=\mathbf{N}^{-\mathbf{1}} \cdot \mathbf{L} \\
\mathbf{v}=\mathbf{A} \cdot \mathbf{Q}_{\mathbf{X}}-\mathbf{d l} \\
m 0_{p o s t}=\sqrt{\frac{[\mathbf{p v v}]}{n-k}} \\
\mathbf{C}_{\mathbf{Q x}}=m 0_{\text {post }}^{2} \cdot \mathbf{N}^{-\mathbf{1}} \\
\mathbf{m}_{\mathbf{Q x}}=\operatorname{diag}\left(\sqrt{\mathbf{C}_{\mathbf{Q x}}}\right)
\end{array}\right.
$$

gdzie:

Qx - wektor szukanych parametrów,

N - macierz układu równań normalnych,

A - macierz planu,

p - macierz wag,

L - wektor wyrazów wolnych,

dl - wektor określający różnicę współrzędnych zaobserwowanych i przybliżonych wyznaczonych z modelu,

v - wektor poprawek,

$m 0_{\text {post }}$ - błąd średni jednostkowy, 
$(n-k)$ - liczba stopni swobody,

$\mathbf{C}_{\mathbf{Q x}}$ - macierz wariancyjno-kowariancyjna błędów średnich,

$\mathbf{m}_{\mathbf{Q x}} \quad$ - błędy średnie współrzędnych wyrażone we współrzędnych geocentrycznych XYZ.

\section{Test badawczy oraz wyniki}

$\mathrm{W}$ teście badawczym dokonano wyznaczenia pozycji statku powietrznego Cessna 172 podczas wykonywanego oblotu wokół lotniska wojskowego EPDE w Dęblinie [14]. Na pokładzie statku powietrznego umieszczono odbiornik geodezyjny Topcon HiperPro, który rejestrował obserwacje GPS/GLONASS w trybie kinematycznym. Na podstawie zarejestrowanych obserwacji kodowych GPS/GLONASS wyznaczono pozycje statku powietrznego zgodnie $\mathrm{z}$ równaniami (1), (2), (3), obliczenia wykonano w programie RTKLIB v.2.4.2 [15]. W pierwszym etapie wyznaczono współrzędne SP w układzie geocentrycznym XYZ oraz wartości precyzji w postaci błędów średnich współrzędnych statku powietrznego (parametry $\mathbf{m}_{\mathbf{Q x}} \mathrm{w}$ modelu stochastycznym $\mathrm{z}$ równania (4)). Błędy średnie współrzędnych statku powietrznego Cessna 172 z rozwiązania GPS, GLONASS oraz GPS/GLONASS zostały określone jak poniżej [16]:

$$
\left\{\begin{array}{l}
m x=\mathbf{m}_{\mathbf{Q x}}(1,1) \\
m y=\mathbf{m}_{\mathbf{Q x}}(2,2) \\
m z=\mathbf{m}_{\mathbf{Q x}}(3,3)
\end{array}\right.
$$

gdzie:

$m x$ - błąd średni współrzędnej X statku powietrznego,

$m y$ - błąd średni współrzędnej Y statku powietrznego,

$m z$ - błąd średni współrzędnej Z statku powietrznego.

$\mathrm{Na}$ rys. 1 pokazano wartości precyzji wyznaczenia współrzędnych statku powietrznego Cessna 172 z rozwiązania GPS. Wartości precyzji zostały zaprezentowane $\mathrm{w}$ postaci błędów średnich współrzędnych XYZ, zgodnie ze wzorem (5). Wartości błędów średnich wzdłuż osi X wynoszą od 2,8 $\mathrm{m}$ do 5,8 $\mathrm{m}$. Ponadto wartość przeciętna parametru $m x$ jest równa $3,5 \mathrm{~m}$, zaś mediana odpowiednio wynosi 3,1 m. Wartości błędów średnich wzdłuż osi Y wynoszą od 2,2 $\mathrm{m}$ do 3,1 $\mathrm{m}$. Ponadto wartość przeciętna parametru my jest równa 2,5 m, zaś mediana odpowiednio wynosi $2,4 \mathrm{~m}$. Wartości błędów średnich wzdłuż osi $\mathrm{Z}$ 
wynoszą od 3,4 $\mathrm{m}$ do $6,3 \mathrm{~m}$. Ponadto wartość przeciętna parametru $m z$ jest równa 4,5 m, zaś mediana odpowiednio wynosi 4,4 m.

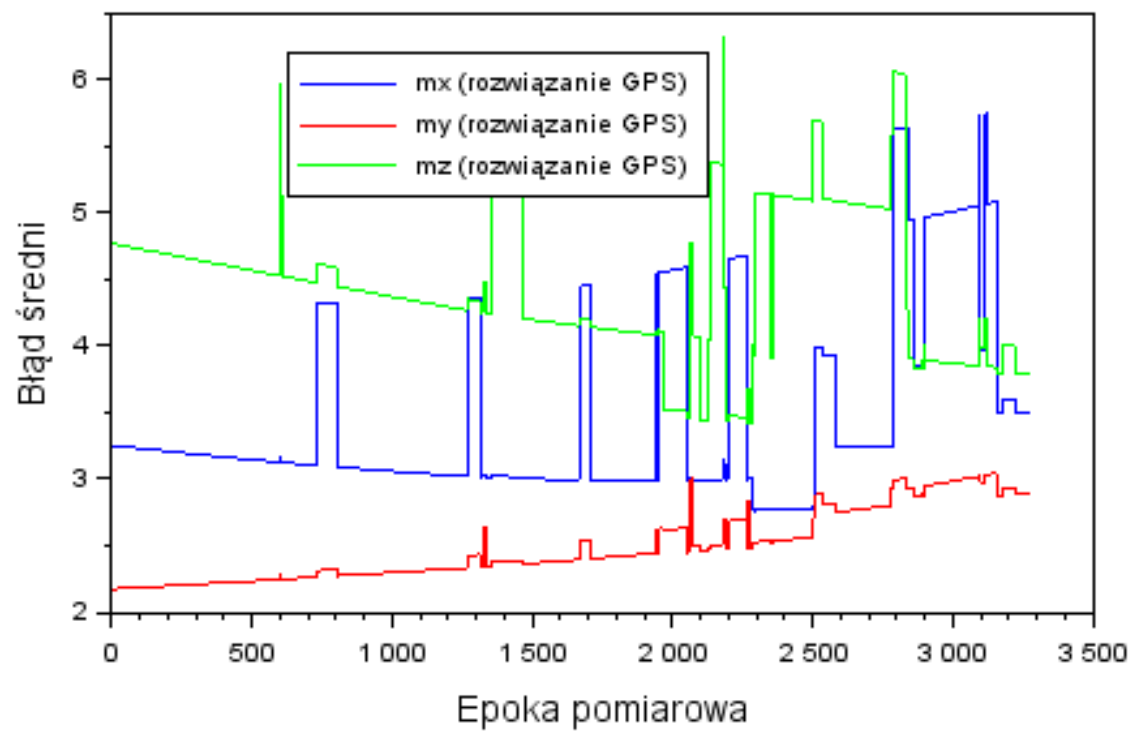

Rys. 1. Błędy średnie współrzędnych XYZ statku powietrznego z rozwiązania GPS

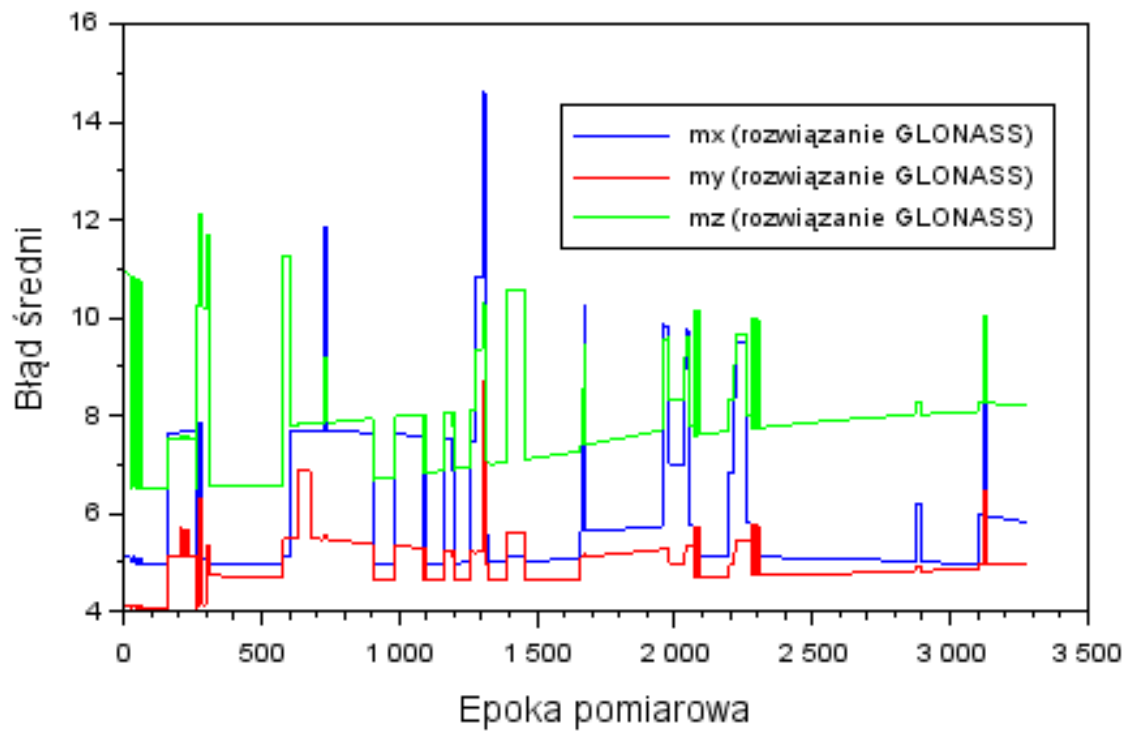

Rys. 2. Błędy średnie współrzędnych XYZ statku powietrznego z rozwiązania GLONASS 
Na rys. 2 pokazano wartości precyzji wyznaczenia współrzędnych SP Cessna 172 z rozwiązania GLONASS. Wartości precyzji zostały zaprezentowane w postaci błędów średnich współrzędnych XYZ, zgodnie ze wzorem (5). Wartości błędów średnich wzdłuż osi X wynoszą od $5 \mathrm{~m}$ do 14,6 m. Ponadto wartość przeciętna parametru $m x$ jest równa 5,9 m, zaś mediana odpowiednio wynosi 5,1 m. Wartości błędów średnich wzdłuż osi $\mathrm{Y}$ wynoszą od $4 \mathrm{~m}$ do $8,7 \mathrm{~m}$. Ponadto wartość przeciętna parametru $m y$ jest równa $5 \mathrm{~m}$, zaś mediana odpowiednio wynosi $4,8 \mathrm{~m}$. Wartości błędów średnich wzdłuż osi $\mathrm{Z}$ wynoszą od $6,5 \mathrm{~m}$ do $12,1 \mathrm{~m}$. Ponadto wartość przeciętna parametru $m z$ jest równa $7,8 \mathrm{~m}$, zaś mediana odpowiednio wynosi $7,7 \mathrm{~m}$.

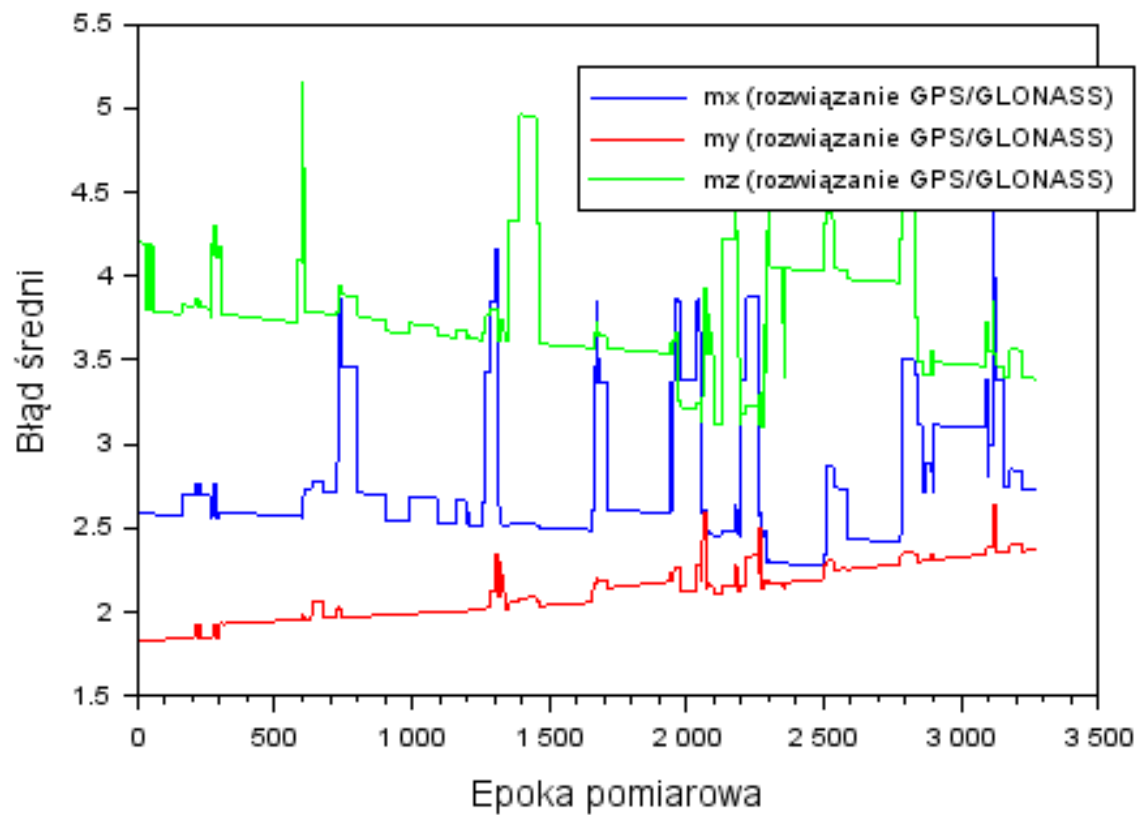

Rys. 3. Błędy średnie współrzędnych XYZ statku powietrznego z rozwiązania GPS/GLONASS

Na rys. 3 pokazano wartości precyzji wyznaczenia współrzędnych SP Cessna 172 z rozwiązania GPS/GLONASS. Wartości precyzji zostały zaprezentowane w postaci błędów średnich współrzędnych XYZ, zgodnie ze wzorem (5). Wartości błędów średnich wzdłuż osi $\mathrm{X}$ wynoszą od 2,3 m do 4,4 m. Ponadto wartość przeciętna parametru $m x$ jest równa $2,7 \mathrm{~m}$, zaś mediana odpowiednio wynosi 2,6 $\mathrm{m}$. Wartości błędów średnich wzdłuż osi $Y$ wynoszą od 1,8 $\mathrm{m}$ do 2,6 m. Ponadto wartość przeciętna parametru $m y$ jest równa $2,2 \mathrm{~m}$, zaś mediana odpowiednio 
wynosi 2,1 m. Wartości błędów średnich wzdłuż osi $Z$ wynoszą od 3,1 m do 5,2 m. Ponadto wartość przeciętna parametru $m z$ jest równa $3,8 \mathrm{~m}$, zaś mediana odpowiednio wynosi 3,7 m.

W kolejnym etapie dokonano określenia dokładności pozycjonowania kodowego GPS, GLONASS oraz GPS/GLONASS w lotnictwie. W tym celu porównano współrzędne SP z rozwiązania kodowego GPS, GLONASS oraz GPS/GLONASS względem precyzyjnej trajektorii lotu określonej $\mathrm{z}$ techniki różnicowej RTK-OTF [17]. Precyzyjna trajektoria lotu z techniki różnicowej RTKOTF została wyznaczona z użyciem obserwacji fazowych GNSS zarejestrowanych przez pokładowy odbiornik oraz lokalną stację referencyjną, zainstalowaną na lotnisku w Dęblinie. W technice różnicowej RTK-OTF wyznaczenie pozycji SP jest możliwe dzięki synchronizacji obserwacji fazowych przez pokładowy odbiornik oraz fizyczną stacje referencyjną GNSS na określony moment czasu. Dzięki technice różnicowej RTK-OTF pozycja SP jest określona z błędem średnim na poziomie około $10 \mathrm{~cm}$.

Dokładność pozycjonowania kodowego GPS, GLONASS oraz GPS/GLONASS została określona zgodnie z równaniem (6) oraz (7), jak poniżej:

- w układzie geocentrycznym XYZ [18]:

$$
\left\{\begin{array}{c}
D X=X-X_{R T K-O T F} \\
D Y=Y-Y_{R T K-O T F} \\
D Z=Z-Z_{\text {RTK-OTF }}
\end{array}\right.
$$

gdzie:

$D X$ - dokładność pozycjonowania wzdłuż osi X,

$D Y$ - dokładność pozycjonowania wzdłuż osi Y,

$D Z$ - dokładność pozycjonowania wzdłuż osi Z,

$(X, Y, Z)$ - wyznaczone współrzędne geocentryczne XYZ statku powietrznego z rozwiązania kodowego GPS, GLONASS oraz GPS/GLONASS (patrz równania (1), (2), (3)),

$\left(X_{R T K-O T F}, Y_{R T K-O T F}, Z_{R T K-O T F}\right)$ - precyzyjna trajektoria lotu statku powietrznego w układzie geocentrycznym XYZ z rozwiązania fazowego RTK-OTF;

- w układzie elipsoidalnym BLh [19]:

$$
\left\{\begin{array}{l}
d B=B-B_{R T K-O T F} \\
d L=L-L_{R T K-O T F} \\
d h=h-h_{R T K-O T F}
\end{array}\right.
$$


gdzie:

$d B$ - dokładność pozycjonowania wzdłuż osi B,

$d L$ - dokładność pozycjonowania wzdłuż osi L,

$d h$ - dokładność pozycjonowania wzdłuż osi h,

$(B, L, h)$ - współrzędne statku powietrznego w układzie elipsoidalnym BLh, powstałe w wyniku transformacji współrzędnych XYZ do BLh,

$\left(B_{R T K-O T F}, L_{R T K-O T F}, h_{R T K-O T F}\right)$ - precyzyjna trajektoria lotu statku powietrznego w układzie elipsoidalnym BLh z rozwiązania fazowego RTK-OTF.

Na rys. 4 przedstawiono rezultaty dokładności pozycjonowania kodowego GPS w układzie geocentrycznym XYZ. Dokładność pozycjonowania GPS dla samolotu Cessna 172 wzdłuż osi $X$ wyniosła od $-9 \mathrm{~m}$ do $-0,3 \mathrm{~m}$. Ponadto średnia dokładność pozycjonowania GPS jest równa -4,6 m, zaś błąd RMS wynosi 4,7 m. Dokładność pozycjonowania GPS dla statku powietrznego Cessna 172 wzdłuż osi Y wyniosła od -2,6 $\mathrm{m}$ do $+1,1 \mathrm{~m}$. Ponadto średnia dokładność pozycjonowania GPS jest równa $-0,2 \mathrm{~m}$, zaś błąd RMS wynosi $0,5 \mathrm{~m}$. Dokładność pozycjonowania GPS dla SP Cessna 172 wzdłuż osi $Z$ wyniosła od $-5,2 \mathrm{~m}$ do $-0,2 \mathrm{~m}$. Ponadto średnia dokładność pozycjonowania GPS jest równa -3 m, zaś błąd RMS wynosi $3,1 \mathrm{~m}$.

Na rys. 5 przedstawiono rezultaty dokładności pozycjonowania kodowego GPS w układzie elipsoidalnym BLh. Dokładność pozycjonowania GPS dla SP Cessna 172 wzdłuż dla składowej B wyniosła od $-1,8 \mathrm{~m}$ do $+4,7 \mathrm{~m}$. Ponadto średnia dokładność pozycjonowania GPS jest równa $+1,5 \mathrm{~m}$, zaś błąd RMS wynosi 1,9 m. Dokładność pozycjonowania GPS dla samolotu Cessna 172 wzdłuż dla składowej $\mathrm{L}$ wyniosła od $+0,3 \mathrm{~m}$ do $+2,8 \mathrm{~m}$. Ponadto średnia dokładność pozycjonowania GPS jest równa $+1,6 \mathrm{~m}$, zaś błąd RMS wynosi również 1,6 m. Dokładność pozycjonowania GPS dla SP Cessna 172 wzdłuż dla składowej h wyniosła od 9,1 m do -1,9 m. Ponadto średnia dokładność pozycjonowania GPS jest równa $5,1 \mathrm{~m}$, zaś błąd RMS wynosi $5,1 \mathrm{~m}$. 


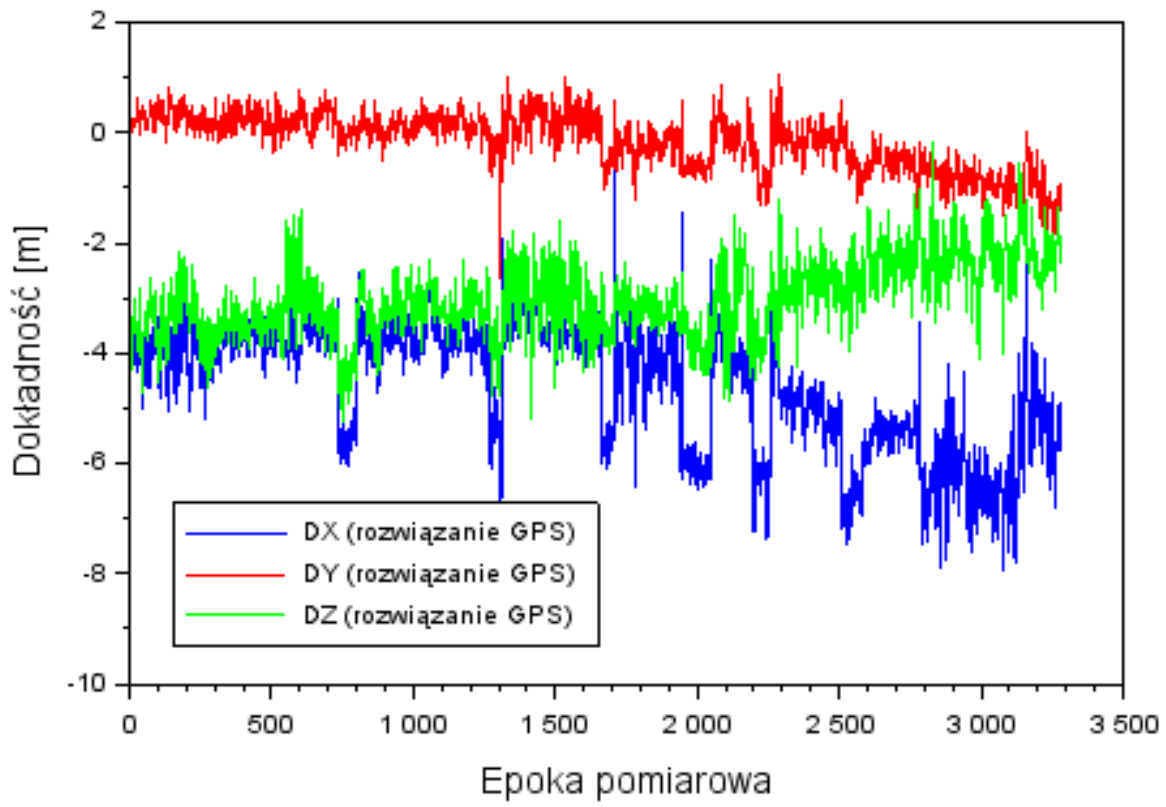

Rys. 4. Dokładność pozycjonowania kodowego GPS we współrzędnych geocentrycznych XYZ

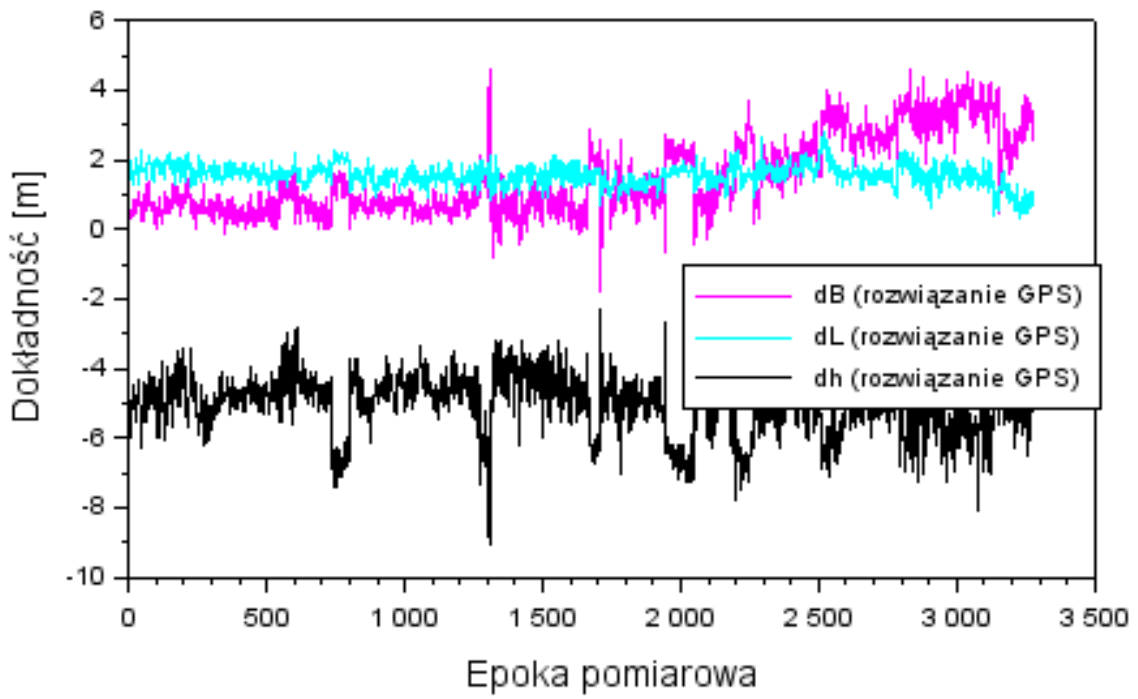

Rys. 5. Dokładność pozycjonowania kodowego GPS we współrzędnych elipsoidalnych BLh 


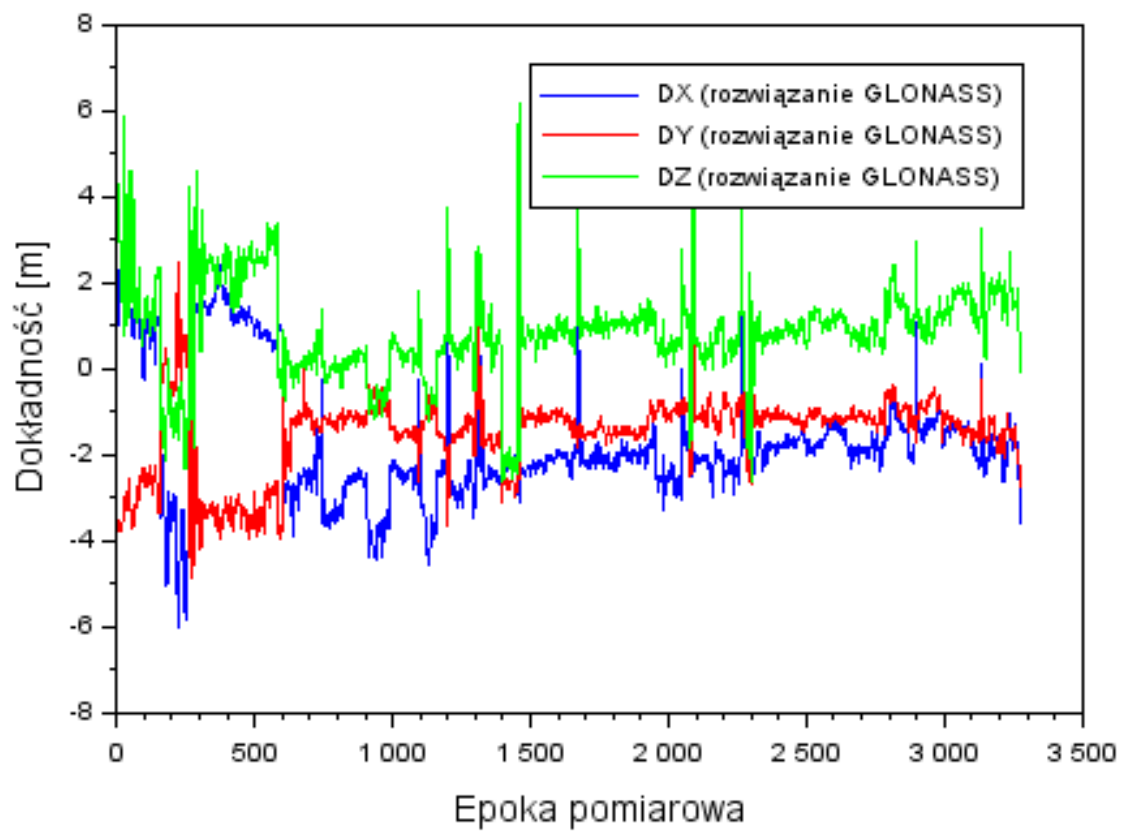

Rys. 6. Dokładność pozycjonowania kodowego GLONASS we współrzędnych geocentrycznych XYZ

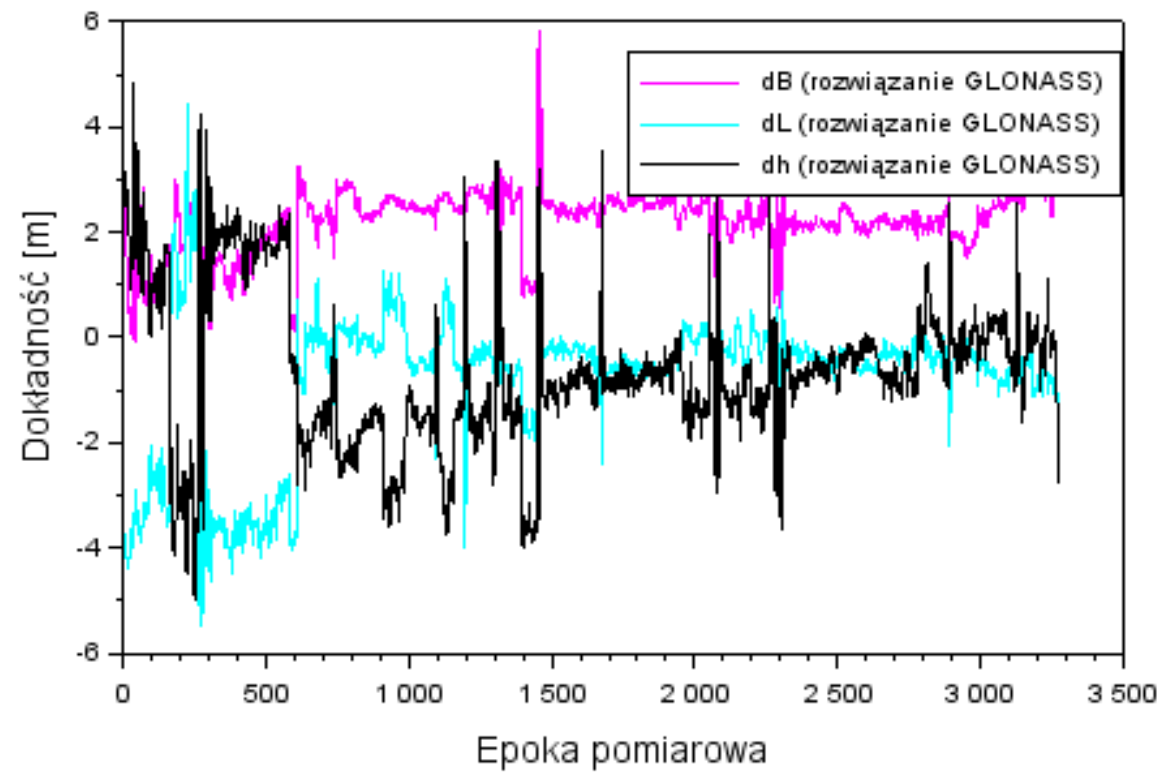

Rys. 7. Dokładność pozycjonowania kodowego GLONASS we współrzędnych elipsoidalnych BLh 
Na rys. 6 przedstawiono rezultaty dokładności pozycjonowania kodowego GLONASS w układzie geocentrycznym XYZ. Dokładność pozycjonowania GLONASS dla SP Cessna 172 wzdłuż osi $X$ wyniosła od $-6 \mathrm{~m}$ do $+3,4 \mathrm{~m}$. Ponadto średnia dokładność pozycjonowania GLONASS jest równa $-2 \mathrm{~m}$, zaś błąd RMS wynosi 2,2 m. Dokładność pozycjonowania GLONASS dla SP Cessna 172 wzdłuż osi Y wyniosła od $-4,9 \mathrm{~m}$ do $+2,5 \mathrm{~m}$. Ponadto średnia dokładność pozycjonowania GLONASS jest równa $-1,3 \mathrm{~m}$, zaś błąd RMS wynosi 1,8 m. Dokładność pozycjonowania GLONASS dla SP Cessna 172 wzdłuż osi $Z$ wyniosła od -2,6 m do $+6,1 \mathrm{~m}$. Ponadto średnia dokładność pozycjonowania GLONASS jest równa $+0,8 \mathrm{~m}$, zaś błąd RMS wynosi 1,3 m.

Na rys. 7 przedstawiono rezultaty dokładności pozycjonowania kodowego GLONASS w układzie elipsoidalnym BLh. Dokładność pozycjonowania GLONASS dla SP Cessna 172 wzdłuż dla składowej B wyniosła od $-0,3 \mathrm{~m}$ do $+5,8 \mathrm{~m}$. Ponadto średnia dokładność pozycjonowania GLONASS jest równa +2,3 m, zaś błąd RMS wynosi 2,2 m. Dokładność pozycjonowania GLONASS dla SP Cessna 172 wzdłuż dla składowej L wyniosła od $-5,5 \mathrm{~m}$ do $+4,8 \mathrm{~m}$. Ponadto średnia dokładność pozycjonowania GLONASS jest równa -0,5 m, zaś błąd RMS wynosi również $1,5 \mathrm{~m}$. Dokładność pozycjonowania GLONASS dla statku powietrznego Cessna 172 wzdłuż dla składowej h wyniosła od $-5 \mathrm{~m}$ do $+4,8 \mathrm{~m}$. Ponadto średnia dokładność pozycjonowania GLONASS jest równa $-0,8 \mathrm{~m}$, zaś błąd RMS wynosi 1,6 m.

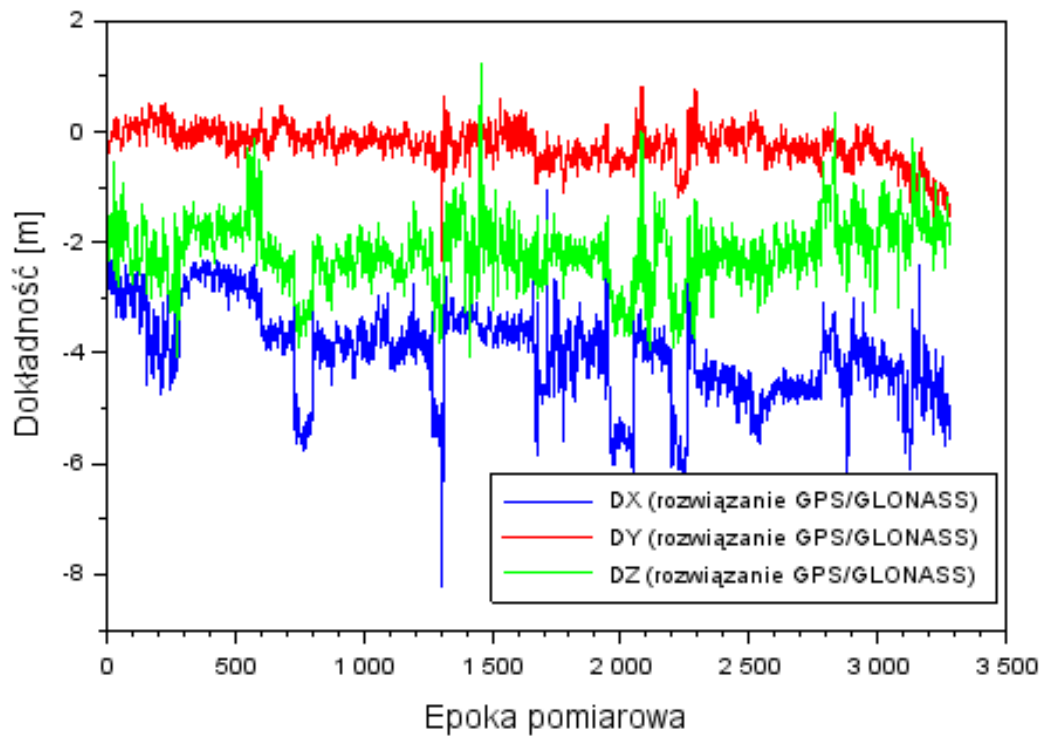

Rys. 8. Dokładność pozycjonowania kodowego GPS/GLONASS we współrzędnych geocentrycznych XYZ 


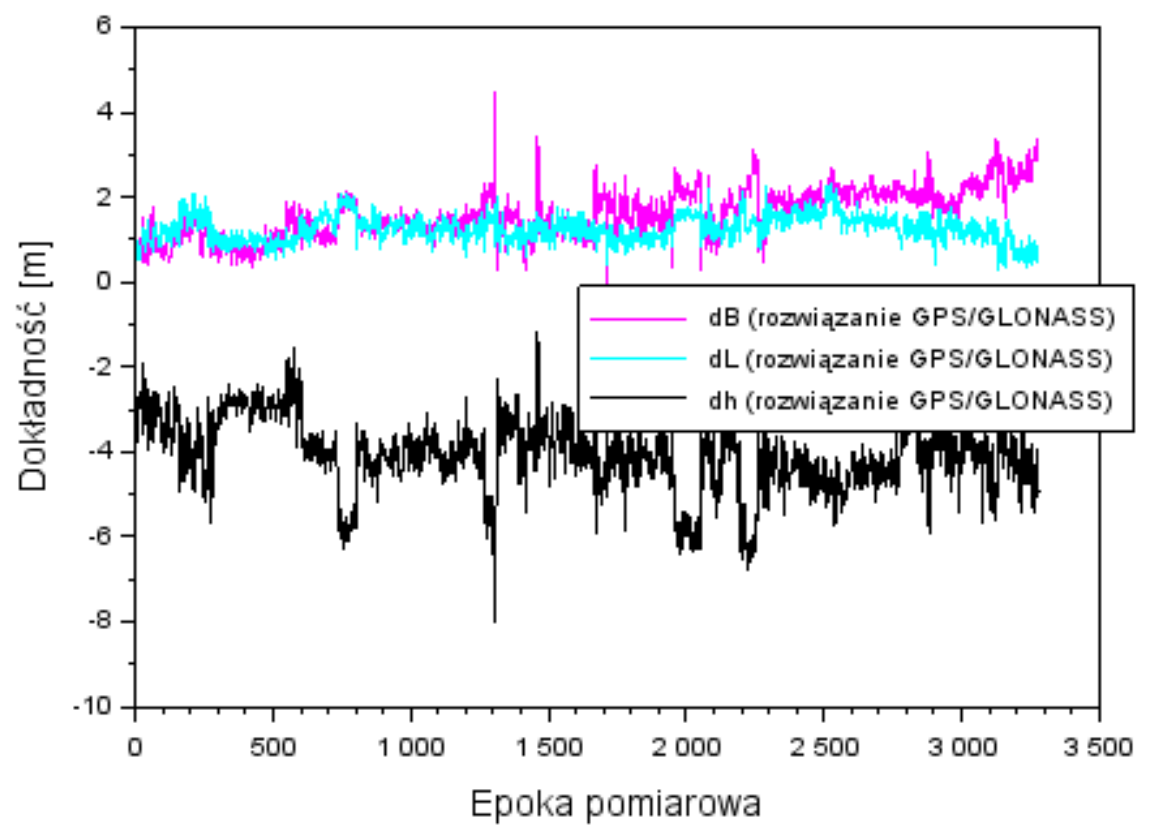

Rys. 9. Dokładność pozycjonowania kodowego GPS/GLONASS we współrzędnych elipsoidalnych BLh

Na rys. 8 przedstawiono rezultaty dokładności pozycjonowania kodowego GPS/GLONASS w układzie geocentrycznym XYZ. Dokładność pozycjonowania GPS/GLONASS dla SP Cessna 172 wzdłuż osi X wyniosła od $-8,2 \mathrm{~m}$ do $-1 \mathrm{~m}$. Ponadto średnia dokładność pozycjonowania GPS/GLONASS jest równa -3,9 m, zaś błąd RMS wynosi 4,1 m. Dokładność pozycjonowania GPS/GLONASS dla SP Cessna 172 wzdłuż osi $\mathrm{Y}$ wyniosła od $-2,3 \mathrm{~m}$ do $+0,8 \mathrm{~m}$. Ponadto średnia dokładność pozycjonowania GPS/GLONASS jest równa -0,2 $\mathrm{m}$, zaś błąd RMS wynosi 0,4 m. Dokładność pozycjonowania GPS/GLONASS dla SP Cessna 172 wzdłuż osi $\mathrm{Z}$ wyniosła od $-4,1 \mathrm{~m}$ do $+1,2 \mathrm{~m}$. Ponadto średnia dokładność pozycjonowania GPS/GLONASS jest równa $-2,2 \mathrm{~m}$, zaś błąd RMS wynosi $2,3 \mathrm{~m}$.

$\mathrm{Na}$ rys. 9 przedstawiono rezultaty dokładności pozycjonowania kodowego GPS/GLONASS w układzie elipsoidalnym BLh. Dokładność pozycjonowania GPS/GLONASS dla SP Cessna 172 wzdłuż dla składowej B wyniosła od -0,2 m do $+4,9 \mathrm{~m}$. Ponadto średnia dokładność pozycjonowania GPS/GLONASS jest równa $+1,6 \mathrm{~m}$, zaś błąd RMS wynosi 1,7 m. Dokładność pozycjonowania GPS/GLONASS dla SP Cessna 172 wzdłuż dla składowej L wyniosła od $+0,3 \mathrm{~m}$ do $+2,4 \mathrm{~m}$. Ponadto średnia dokładność pozycjonowania GPS/GLONASS jest równa $+1,3 \mathrm{~m}$, zaś błąd RMS wynosi również 1,3 m. Dokładność pozycjonowania 
GPS/GLONASS dla SP Cessna 172 wzdłuż dla składowej h wyniosła od $-8 \mathrm{~m}$ do $-1,1 \mathrm{~m}$. Ponadto średnia dokładność pozycjonowania GPS/GLONASS jest równa $-4,1 \mathrm{~m}$, zaś błąd RMS wynosi 4,2 $\mathrm{m}$.

\section{Wnioski}

W pracy przedstawiono rezultaty dokładności pozycjonowania kodowego z rozwiązania GPS, GLONASS oraz GPS/GLONASS w lotnictwie. W teście badawczym wykorzystano pokładowe dane GPS/GLONASS z odbiornika Topcon HiperPro, zamontowanego w samolocie Cessna 172. Ponadto do określenia precyzyjnej trajektorii odniesienia lotu SP Cessna 172 zastosowano technikę różnicową RTK-OTF. W związku z tym w obliczeniach w technice różnicowej RTK-OTF wykorzystano pokładowe dane GNSS z odbiornika Topcon hiperPro oraz obserwacje fazowe ze stacji referencyjnej GNSS zainstalowanej na terenie lotniska wojskowego w Dęblinie. Na podstawie przeprowadzonych badań stwierdzono, że:

- najwyższa dokładność pozycjonowania wzdłuż osi X jest dla rozwiązania kodowego GLONASS, zaś najmniejsza dla rozwiązania kodowego GPS,

- najwyższa dokładność pozycjonowania wzdłuż osi Y jest dla rozwiązania kodowego GPS, zaś najmniejsza dla rozwiązania kodowego GLONASS,

- najwyższa dokładność pozycjonowania wzdłuż osi Z jest dla rozwiązania kodowego GLONASS, zaś najmniejsza dla rozwiązania kodowego GPS,

- najmniejsza wartość błędu RMS wzdłuż osi X jest dla rozwiązania kodowego GLONASS, zaś najwyższa dla rozwiązania kodowego GPS,

- najmniejsza wartość błędu RMS wzdłuż osi Y jest dla rozwiązania kodowego GPS/GLONASS, zaś najwyższa dla rozwiązania kodowego GLONASS,

- najmniejsza wartość błędu RMS wzdłuż osi Z jest dla rozwiązania kodowego GLONASS, zaś najwyższa dla rozwiązania kodowego GPS,

- najwyższa dokładność pozycjonowania dla składowej $B$ jest dla rozwiązania kodowego GPS, zaś najmniejsza dla rozwiązania kodowego GLONASS,

- najwyższa dokładność pozycjonowania dla składowej L jest dla rozwiązania kodowego GLONASS, zaś najmniejsza dla rozwiązania kodowego GPS,

- najwyższa dokładność pozycjonowania dla składowej h jest dla rozwiązania kodowego GLONASS, zaś najmniejsza dla rozwiązania kodowego GPS, 
- najmniejsza wartość błędu RMS wzdłuż osi B jest dla rozwiązania kodowego GPS/GLONASS, zaś najwyższa dla rozwiązania kodowego GLONASS,

- najmniejsza wartość błędu RMS wzdłuż osi L jest dla rozwiązania kodowego GPS/GLONASS, zaś najwyższa dla rozwiązania kodowego GPS,

- najmniejsza wartość błędu RMS wzdłuż osi h jest dla rozwiązania kodowego GLONASS, zaś najwyższa dla rozwiązania kodowego GPS.

\section{Podzieckowanie}

Artykut zostat sfinansowany przez Lotnicza Akademię Wojskowa w ramach badań statutowych na 2019 rok.

\section{References}

1. International Civil Aviation Organization: ICAO standards and recommended practices (SARPS). Annex 10 volume I (Radio navigation aids), 2006.

2. Misra P.N., Abbot R.I., Gaposcbkin E.M.: Integrated Use of GPS and GLONASS: Transformation Between WGS 84 and PZ-90. Proceedings of the 9th International Technical Meeting of the Satellite Division of The Institute of Navigation (ION GPS 1996), Kansas City, MO, September 1996.

3. Januszewski J.: Perspektywy rozwoju nawigacyjnych i wspomagających systemów satelitarnych w bliskiej i dalszej przyszłości. Przegląd Telekomunikacyjny + Wiadomości Telekomunikacyjne, No. 5, 2014.

4. Jafernik H., Ćwiklak J., Krasuski K.: Wykorzystanie programu gLAB w precyzyjnym pozycjonowaniu statku powietrznego w transporcie lotniczym - testy lotnicze w Dęblinie i Mielcu. Przegląd Komunikacyjny, year 73, no 1, 2018.

5. Przestrzelski P.: Sieciowe pozycjonowanie różnicowe z wykorzystaniem obserwacji GPS i GLONASS. PhD dissertation, Olsztyn 2016.

6. Krasuski K, Ćwiklak J.: Application of the GLONASS code observations for the designation of coordinates of an aircraft in flight test mode: a case study. Scientific Journal of Silesian University of Technology. Series Transport, Vol. 97, 2017, DOI: https://doi.org/10.20858/sjsutst.2017.97.7.

7. IS-GPS-200D-001: Interface Specification IS-GPS-200 Revision D. NAVSTAR Global Positioning System, 2006.

8. Santerre R., Pan L., Cai C., Zhu J.: Single Point Positioning Using GPS, GLONASS and BeiDou Satellites. Positioning, 2014, vol. 5, DOI: 10.4236/pos.2014.54013.

9. Ćwiklak J., Krasuski K., Jafernik H.: Designation the velocity of Cessna 172 aircraft based on GPS data in flight test. 23rdInternational Conference ENGINEERING MECHANICS 2017, Svratka, Czech Republic, 15-18 May 2017. 
10. Bakuła M.: Pozycjonowanie autonomiczne z wykorzystaniem obserwacji GPS. Zeszyty Naukowe WSOSP, No. 1, 2014.

11. Roßbrach U.: Positioning and Navigation using Russian Satellite System GLONASS. Ph. D. Thesis, Monachium, 2000.

12. Krasuski K.: Wykorzystanie obserwacji GPS/GLONASS do wyznaczenia pozycji statku powietrznego. Zeszyty Naukowe WSOSP, No. 4, 2015.

13. Osada E.: Geodezja. Oficyna Wydawnicza Politechniki Wrocławskiej, Wrocław, 2001.

14. Krasuski K., Ćwiklak J., Grzesik N.: Accuracy assessment of aircraft positioning by using the DGLONASS method in GBAS system. Journal of KONBIN, Vol. 45, 2018, DOI: $10.1515 /$ jok-2018-0006.

15. Takasu T.: RTKLIB ver. 2.4.2 Manual, RTKLIB: An Open Source Program Package for GNSS Positioning, 2013, Paper available at website:

http://www.rtklib.com/prog/manual_2.4.2.pdf, current on 2019.

16. Siejka Z.: Wykorzystanie pomiarów gnss do wyznaczania współrzędnych podstawowej osnowy realizacyjnej na terenach oddziaływań górniczych. Archiwum Fotogrametrii, Kartografii i Teledetekcji, Vol. 19, 2009.

17. Grzegorzewski M.: Navigating an aircraft by means of a position potential in three dimensional space. Annual of Navigation, No. 9, 2005.

18. Bakuła, M.: Static code DGPS positioning based on three reference stations. Geodesy and Cartography, Vol. 54, No 2, 2005.

19. Świątek A., Jaworski L., Tomasik Ł.: EGNOS Monitoring Prepared in Space Research Centre P.A.S. for SPMS Project. Artificial Satellites, Vol. 52, No. 4, 2017, DOI: 10.1515/arsa-2017-0010. 